\title{
Phycoerythrin from Colaconema sp. Has Immunostimulatory Effects on the Whiteleg Shrimp Litopenaeus vannamei and Increases Resistance to Vibrio parahaemolyticus and White Spot Syndrome Virus
}

\author{
Po-Tsang Lee ${ }^{1}$, Jing Huang ${ }^{1}$, Chin-Yi Huang ${ }^{1}$, Zi-Xuan Liu ${ }^{1}$, Han-Yang Yeh ${ }^{1}{ }^{\circledR}$, Huai-Ting Huang ${ }^{1}$, \\ Li-Li Chen ${ }^{2,3} \mathbb{C}$, Fan-Hua Nan ${ }^{1,4}$ and Meng-Chou Lee ${ }^{1,3,4, *(\mathbb{C})}$
}

1 Department of Aquaculture, National Taiwan Ocean University, Keelung City 20224, Taiwan; leepotsang@mail.ntou.edu.tw (P.-T.L.); haungjim31336@gmail.com (J.H.); thormars@gmail.com (C.-Y.H.); lzxuan08@gmail.com (Z.-X.L.); 20833001@mail.ntou.edu.tw (H.-Y.Y.); twinkleqazwsx784@gmail.com (H.-T.H.); fhnan@mail.ntou.edu.tw (F.-H.N.)

2 Institute of Marine Biology, National Taiwan Ocean University, Keelung City 20224, Taiwan; joechen@ntou.edu.tw

3 Center of Excellence for the Oceans, National Taiwan Ocean University, Keelung City 20224, Taiwan

4 Center of Excellence for Ocean Engineering, National Taiwan Ocean University, Keelung City 20224, Taiwan

* Correspondence: mengchoulee@email.ntou.edu.tw; Tel.: +886-22462-2192 (ext. 5239) or +886-978-586-589; Fax: +886-22463-5441

Citation: Lee, P.-T.; Huang, J.; Huang, C.-Y.; Liu, Z.-X.; Yeh, H.-Y.; Huang, H.-T.; Chen, L.-L.; Nan, F.-H.; Lee, M.-C. Phycoerythrin from Colaconema sp. Has Immunostimulatory Effects on the Whiteleg Shrimp Litopenaeus vannamei and Increases Resistance to Vibrio parahaemolyticus and White Spot Syndrome Virus. Animals 2021 11, 2371. https://doi.org/10.3390/ ani11082371

Academic Editor: Benjamín Costas

Received: 1 July 2021

Accepted: 9 August 2021

Published: 11 August 2021

Publisher's Note: MDPI stays neutral with regard to jurisdictional claims in published maps and institutional affiliations.

Copyright: () 2021 by the authors. Licensee MDPI, Basel, Switzerland. This article is an open access article distributed under the terms and conditions of the Creative Commons Attribution (CC BY) license (https:// creativecommons.org/licenses/by/ $4.0 /)$.
Simple Summary: In this study, we found that phycoerythrin from Colaconema sp. can differentially stimulate the immune response of whiteleg shrimp in vitro and in vivo and could potentially be used as an immunomodulator in shrimp culture.

\begin{abstract}
We investigated whether phycoerythrin (PE), a pigment sourced from marine algae, could act as an immunomodulatory agent in whiteleg shrimp (Litopenaeus vannamei). To this end, PE was extracted and purified from a PE-rich macroalgae, Colaconema sp. Our in vitro analysis demonstrated that PE enhanced prophenoloxidase and phagocytosis activity but inhibited the production of reactive oxygen species in hemocytes. Additionally, the PE signal could be detected using an in vivo imaging system after its injection into the ventral sinus of the cephalothorax of whiteleg shrimp. The expression profiles of fourteen immune-related genes were monitored in hemocytes from whiteleg shrimp injected with $0.30 \mu \mathrm{g}$ of PE per gram of body weight, and crustin, lysozyme, penaiedin 4 , and anti-lipopolysaccharide factor showed up-regulated post-stimulation. The induction of immune genes and enhancement of innate immune parameters by PE may explain the higher survival rates for shrimp that received different doses of PE prior to being challenged with Vibrio parahaemolyticus or white spot syndrome virus compared to controls. Combined, these results show that PE from Colaconema sp. can differentially stimulate the immune response of whiteleg shrimp in vitro and in vivo and could potentially be used as an immunomodulator in shrimp culture.
\end{abstract}

Keywords: phycoerythrin; shrimp; innate immunity; vibrio; WSSV

\section{Introduction}

Due to global improvements in the quality of life, the international demand for shrimp has been increasing. In 2019, the estimated global production of cultured marine shrimp was 4.45 million metric tonnes. However, global shrimp production in 2020 is predicted to have been severely reduced due to the COVID-19 pandemic [1]. Litopenaeus vannamei, also known as whiteleg shrimp, is one of the most important cultured shrimp species worldwide. L. vannamei is described as having a wide range of salt tolerance, rapid growth, and a high survival rate, as well as being well suited for artificial reproduction and highdensity culture, and has thus become the main cultured shrimp species in Taiwan [2]. In 
2016, the production of L. vannamei was 4.15 million metric tons, which constituted more than $80 \%$ of the total shrimp production [3]. However, the rapid growth of comprehensive and industrialized shrimp culture systems has been negatively affected by the incidence and dissemination of various infectious diseases, such as vibriosis and viral diseases.

Vibriosis is attributable to the Gram-negative bacterium Vibrio spp. [4,5] and is a great obstacle for whiteleg shrimp aquaculture, as infections result in high mortality in farming operations. There are several Vibrio species that have been identified as infectious agents in penaeid shrimp, such as Vibrio harveyi, $V$. parahaemolyticus, and $V$. alginolyticus, which form a majority of the bacterial pathogens that cause severe losses, particularly in hatcheries [6-8]. Additionally, approximately 20 viruses have been reported in shrimp culture. Among these viruses, the white spot syndrome virus (WSSV) has had a considerable impact on shrimp culture and, at present, still causes a serious disease problem [9]. WSSV is reported to spread via contaminated water and cannibalism of infected shrimp [10]. Therefore, the improvement of immunity and disease resistance in whiteleg shrimp has become crucial for the continuous growth of the shrimp aquaculture industry [11].

Seaweeds are rich in proteins, vitamins, carbohydrates, fibers, lipids, and minerals. Moreover, seaweeds have abundant polysaccharides, such as fucoidan, lipopolysaccharide, peptidoglycans, sodium alginate, and glucan $[12,13]$. Previous investigations have focused on the impact of these substances on reducing the mortality caused by microbes [14,15], improving immune system function [12,16], and increasing the resistance to ammonia stress in shrimp [17]. However, the effects of other components in macroalgae on aquatic animals have rarely been studied. Red algae possess pigments such as phycoerythrin (PE), phycocyanin (PC), and allophycocyanin (APC), along with other pigments such as chlorophyll a, beta-carotene, and a number of unique xanthophylls $[18,19]$. PE is considered a recently evolved phycobiliprotein, broadening the cyanobacterial photon absorbance ability toward the blue end of the visible solar spectrum [20]. PE consists of $\alpha$ and $\beta$ subunits that contain 160 to 180 amino acids [21,22]. These subunits have a covalently attached open-chain tetrapyrrole chromophore, the so-called phycoerythrobilin [20]. In a few investigations, PE purified from the marine cyanobacterium Phormidium sp. was noted to exhibit antioxidant property against various reactive oxygen species (ROS) [23]. Additionally, PE can extend life expectancy and improve the health of Caenorhabditis elegans [24]. It has been speculated that PE displays life-prolonging and health-promoting effects due to its antioxidant properties $[25,26]$. To our knowledge, the applications of PE extracts in aquatic animals have not yet been explored. The present study, therefore, aims to investigate the effects of PE extracted from Colaconema sp. on whiteleg shrimp.

\section{Materials and Methods}

\subsection{Preparation of Phycoerythrin}

One gram of frozen algae was diluted in $900 \mu \mathrm{L}$ of distilled water (obtained a from greenhouse, Department of Aquaculture, National Taiwan Ocean University). Then, $0.1 \mathrm{~g}$ quartz sand and $1 \mathrm{~mm}$ grinding beads were added to the alga-water mixture and homogenized by a FastPrep- 24 homogenizer (TeenPrep, 6 cycles, $4.0 \mathrm{~m} \cdot \mathrm{s}^{-1}$ for $5 \mathrm{~s}$; MP Biomedicals, Solon, OH, USA). The homogenized mixture was centrifuged at $10,000 \times g$ at $4{ }^{\circ} \mathrm{C}$ for $10 \mathrm{~min}$. The supernatant was collected and transferred to a beaker containing a stir bar and placed on a magnetic stirrer. While the sample was stirring, saturated ammonium sulfate was slowly added to bring the final concentration to $35 \%$ saturation. Once the total volume of ammonium sulfate was added, the beaker was moved to $4{ }^{\circ} \mathrm{C}$ and incubated overnight. The mixture was then transferred to conical tubes and centrifuged at $10,000 \times g$ for 10 min (Hitachi CR 21G; Hitachi Ltd., Tokyo, Japan). The supernatant was carefully collected and transferred to a beaker containing a stir bar and placed on a magnetic stirrer. While the sample was stirring, saturated ammonium sulfate was slowly added to bring the final concentration to $50 \%$ saturation, and then the beaker was again moved to $4{ }^{\circ} \mathrm{C}$ overnight. The mixture was then centrifuged at $10,000 \times g$ for $10 \mathrm{~min}$. The supernatant was carefully removed and discarded, and the conical tube was well-drained. The pellet 
was resuspended in $10-30 \%$ of the starting volume in $1 \times$ phosphate-buffered saline (PBS; $\mathrm{pH}$ 7.0). The resulting PE solution was transferred to dialysis tubing and dialyzed versus three changes of $1 \times$ low salinity PBS.

The PE fraction was loaded on a HiPrep Sephacryl S-300 HR column (GE Healthcare, Chicago, IL, USA), and the loading sample was about $10 \%$ of the column volume. The gel filtration was developed with PBS containing $10 \mathrm{mM} \mathrm{NaCl}$. The flow rate was set at $0.5 \mathrm{~mL}$ per min using a high-pressure peristaltic pump (Ecom LCP4100; Ecom, CZ, Czech Republic) and a UV detector (Ecom LCD 2084; Ecom, CZ, Czech Republic) connected to the rear of the column. The absorption spectra of the phycocyanobilin chromophore were measured on a UV-Vis spectrophotometer (Jasco Spectrophotometer V-630, Jasco, Tokyo, Japan) at the wavelengths 280,498, and $565 \mathrm{~nm}$. The eluate from the liquid chromatograph (Panchum FC-201 Del, Kaohsiung city, Taiwan) was collected after the separation of the different phycobiliproteins. The eluted solution was passed through a $0.22 \mu \mathrm{m}$ filter (Merck Millipore, MA, Burlington).

Chromatographic analysis was performed using a high-performance liquid chromatography (HPLC) system (Thermo Fisher Scientific, Waltham, MA, USA). The separation was performed using a SUPREMA Linear M chromatographic column $(5 \mu \mathrm{m}, 8 \mathrm{~mm} \times 300 \mathrm{~mm}$, PSS) at $40{ }^{\circ} \mathrm{C}$. The mobile phase was made of $0.05 \%(v / v)$ sodium azide in water with a flow rate of $1.0 \mathrm{~mL}$ per min. The column effluent was monitored at $545 \mathrm{~nm}$. The CS-PE was serially diluted $(2,4,8,16,32,64,128$, and 256 times) and the UV absorbance values were used to calculate the phycobiliprotein levels. Fluorescence values were also determined using an excitation wavelength of $485 \mathrm{~nm}$ with emission measured at $590 \mathrm{~nm}$ using a fluorescence-cooled luminescence analyzer (Plate Chameleon; Hidex, Turku, Finland) to establish the content and fluorescence of the eluting solution, then further compared with the standard PE FL52412 (Sigma-Aldrich, St. Louis, MO, USA). The phycobiliprotein concentration was calculated according to the following equations:

$$
\begin{aligned}
& \mathrm{PE}(\mathrm{mg} / \mathrm{mL})=\left(\mathrm{A}_{562}-2.8(\mathrm{PC})-0.34(\mathrm{APC})\right) / 12.7 \\
& \mathrm{PC}(\mathrm{mg} / \mathrm{mL})=\left(\mathrm{A}_{615}-0.7\left(\mathrm{~A}_{652}\right)\right) / 7.38 \\
& \mathrm{APC}(\mathrm{mg} / \mathrm{mL})=\left(\mathrm{A}_{652}-0.19\left(\mathrm{~A}_{615}\right)\right) / 5.65
\end{aligned}
$$

The purity index was measured using chromatography gel filtration and calculated using the formula:

$$
\text { Purity Index }=A_{562} / A_{280}
$$

\subsection{Native (PAGE) and Sodium Dodecyl Sulfate (SDS)-Polyacrylamide Gel Electrophoresis (PAGE) Analysis}

For the native PAGE, the soluble protein concentrations were first analyzed using the Bradford method to quantify the protein concentrations in the samples. Samples $(5 \mu \mathrm{g})$, including the PE purified from this study and commercially available PE (Sigma-Aldrich, St. Louis, MO, USA), were diluted with sample buffer (62.5 mM Tris- $\mathrm{HCl}, \mathrm{pH} 6.8,40 \%$ glycerol, and $0.01 \%$ bromophenol blue) in a 1:1 ratio and separated via electrophoresis at conditions of $5 \%$ pyrochlore colloid and $8 \%$ dissociation gel, at $75 \mathrm{~V}$ and $50 \mathrm{~mA}$. The gel was fixed with fixative (secondary water: methanol: glacial acetic acid $=1: 4: 5$ ) and stained with $0.1 \%$ Coomassie brilliant blue G-250 and was subsequently decolored with the decolorizing solution.

For the SDS-PAGE, quantitative samples $(5 \mu \mathrm{g})$ were mixed 1:1 with sample buffer (0.125 M Tris- $\mathrm{HCl}$ (pH 6.8), 4\% SDS, 20\% glycerol, $0.01 \%$ bromophenol blue, and $10 \%$ B-mercaptoethanol) and heated at $100{ }^{\circ} \mathrm{C}$ for $10 \mathrm{~min}$. The heated sample was injected along with $5 \mu \mathrm{L}$ of protein standard (Bio-Rad, Hercules, CA, USA) into a film consisting of $5 \%$ pyrochlore colloid and $15 \%$ dissociation gel for protein composition analysis. Electrophoresis conditions were $5 \%$ pyrochlore colloid and $8 \%$ dissociation gel, at $75 \mathrm{~V}$ and $50 \mathrm{~mA}$. The gel was fixed with fixative (secondary water: methanol: glacial acetic acid =1:4:5), stained with $0.1 \%$ Coomassie brilliant blue G-250, and decolored with the decolorizing solution. 


\subsection{Experimental Shrimp}

Approximately 200 whiteleg shrimps ( 7 g) were transported from a local farm (Yilan County, Taiwan) to the laboratory within $2 \mathrm{~h}$ by a fish transport truck and allocated to fiberglass circular tanks $\left(1 \mathrm{~m}^{3}\right)$ containing clean aerated water. The whiteleg shrimp were acclimated for 14 days at $27 \pm 1{ }^{\circ} \mathrm{C}$ and were fed with a commercial diet (Tairoun Products Company Ltd., Taiwan) twice a day at $5 \%$ of their total body weight. The water quality parameters such as temperature $\left(25-29{ }^{\circ} \mathrm{C}\right), \mathrm{pH}(7.8-8.1)$, salinity $(33-35 \%$ ), and dissolved oxygen $(5.0-6.0 \mathrm{mg} / \mathrm{L})$ were monitored daily. Additionally, $20 \%$ of culture water was changed daily with fresh clean seawater to maintain the concentrations of ammonia$N$ and nitrite- $N$, detected using a water testing kit (Kyoritsu chemical-check Laboratory Corporation), lower than 0.05 and $0.03 \mathrm{mg} / \mathrm{L}$, respectively.

\subsection{In Vitro Effects of PE on the Immune Response of Hemocytes}

2.4.1. Prophenoloxidase Activity (PO)

Hemolymph withdrawn from ten whiteleg shrimp $(12.0 \pm 1.5 \mathrm{~g})$ was mixed with ice-cold anticoagulant buffer (AC, $450 \mathrm{mM} \mathrm{NaCl}, 10 \mathrm{mM} \mathrm{KCl}, 10 \mathrm{mM}$ HEPES, $10 \mathrm{mM}$ EDTA-Na $2, \mathrm{pH} 7.3)$ at a ratio of 1:9, followed by centrifugation to remove the supernatant. Cells $\left(1 \times 10^{6}\right.$ cells $\left./ \mathrm{mL}\right)$ were incubated for $1 \mathrm{~h}$ with 0 (Control), 8 (T1), 14 (T2), 27 (T3), or 52 (T4) $\mu \mathrm{g} / \mathrm{mL}$ PE at ambient temperature. Subsequently, cells were centrifuged at $800 \times \mathrm{g}$ for $10 \mathrm{~min}$ at $4{ }^{\circ} \mathrm{C}$ and sonicated for $5 \mathrm{~s}$ four times. A $50 \mu \mathrm{L}$ volume of cell suspension was inoculated into a 96-well plate and added with $50 \mu \mathrm{L}$ of a $3 \mathrm{mg} / \mathrm{mL}$ l-dihydroxyphenylalanine solution (L-DOPA, Sigma-Aldrich, St. Louis, MO, USA). PO activity was measured after a $15 \mathrm{~min}$ incubation at room temperature using a microplate reader (BioTek, Winooski, VT, USA) at $490 \mathrm{~nm}[27,28]$.

\subsubsection{Reactive Oxygen Species (ROS) Production}

Production of ROS was measured according to the published methods [29] with a minor modification. In short, hemocytes $\left(1 \times 10^{6}\right.$ cells $\left./ \mathrm{mL}\right)$ in modified complete Hank's balanced salt solution (MCHBSS; $10 \mathrm{mM}$ calcium chloride, $3 \mathrm{mM}$ magnesium chloride, $5 \mathrm{mM}$ magnesium sulfate in HBSS (Gibco, Carlsbad, CA, USA)) were incubated with 0 (Control), 8 (T1), 14 (T2), 27 (T3), or 52 (T4) $\mu \mathrm{g} / \mathrm{mL}$ PE for $30 \mathrm{~min}$ at room temperature in a 96-well plate. The plate was then centrifuged at $800 \times \mathrm{g}$ for $20 \mathrm{~min}$ at $4{ }^{\circ} \mathrm{C}$ and the supernatant was discarded. Subsequently, $100 \mu \mathrm{L}$ of $2^{\prime}, 7^{\prime}$-Dichlorofluoresceindiacetate (DCFH-DA, final concentration of $0.1 \mathrm{mM}$; Sigma-Aldrich, St. Louis, MO, USA) was added into each well and cells were incubated in the dark for $30 \mathrm{~min}$. Then, cells were washed twice with whiteleg shrimp salt solution (SSS) buffer ( $450 \mathrm{mM} \mathrm{NaCl}, 10 \mathrm{mM} \mathrm{KCl}, 10 \mathrm{mM}$ HEPES, pH 7.3). A spectrofluorometer (Synergy H1 Hybrid Multi-Mode Reader; BioTek, Winooski, VT, USA) with an excitation wavelength of $480 \mathrm{~nm}$ and an emission wavelength of $523 \mathrm{~nm}$ was used to measure the fluorescence units (RFU).

\subsubsection{Phagocytosis Rate}

The phagocytosis assay was performed according to published methods [30,31]. Diluted hemolymph $\left(1000 \mu \mathrm{L}, 1 \times 10^{6}\right.$ cells $\left./ \mathrm{mL}\right)$ in MCHBSS was incubated with 0 (Control), 8 (T1), 14 (T2), 27 (T3), or 52 (T4) $\mu \mathrm{g} / \mathrm{mL}$ PE for $30 \mathrm{~min}$ at room temperature. Subsequently, latex beads (carboxylate-modified polystyrene fluorescent yellow-green L4655 $\varnothing=1.0 \mu \mathrm{m}$, Sigma-Aldrich, St. Louis, MO, USA) were added into tubes at a rate of 100 beads per hemocyte and left in the dark for $2 \mathrm{~h}$. Non-engulfed beads were washed off, and cells were rinsed two times with trypan blue $(1.2 \mathrm{mg} / \mathrm{mL})$ [32] before the addition of $1000 \mu \mathrm{L}$ of AC. The phagocytosis rate was examined using BD FACSAria III Flow cytometry (BD Biosciences, Franklin Lakes, NJ, USA).

\subsection{Gene Expression Analysis by Quantitative Real-Time Polymerase Chain Reaction ( $q R T-P C R$ )}

Twenty healthy whiteleg shrimp (body weight $16.08 \pm 0.09 \mathrm{~g}$ ) were injected with $20 \mu \mathrm{L}$ of SSS buffer alone $(n=10)$ or SSS buffer containing PE to achieve doses of $0.30 \mu \mathrm{g} / \mathrm{g}$ 
body weight $(n=10)$ and whiteleg shrimps were maintained at $28^{\circ} \mathrm{C}$ in aquariums during the period of observation. The whiteleg shrimp hemocyte total RNA extraction method was modified from a previous study [33]. Briefly, $500 \mu \mathrm{L}$ of hemocyte was taken at 8 and $24 \mathrm{~h}$ post-injection from 5 whiteleg shrimps. One part of the hemocyte was mixed with one part of AC prior to centrifugation at $800 \times g$ for $10 \mathrm{~min}$. Cells were lysed using $500 \mu \mathrm{L}$ of Trizol Reagent (Sigma-Aldrich, St. Louis, MO, USA) and mixed with $100 \mu \mathrm{L}$ of chloroform. The tubes were vortexed for $10 \mathrm{~s}$, incubated at ambient temperature for $3 \mathrm{~min}$, and centrifuged at $13,000 \times \mathrm{g}$ for $20 \mathrm{~min}$ at $4{ }^{\circ} \mathrm{C}$. The colorless upper aqueous phase was combined with an equal volume of isopropanol (Sigma-Aldrich, St. Louis, MO, USA) followed by a $10 \mathrm{~min}$ incubation at ambient temperature. Samples were then centrifuged at $13,000 \times g$ for $10 \mathrm{~min}$ at $4{ }^{\circ} \mathrm{C}$. The supernatant was discarded and the precipitated RNA pellet was washed with $1 \mathrm{~mL}$ of $75 \%$ ethanol twice and air-dried. Twenty microliters of nuclease-free water (Thermo Fisher Scientific, Waltham, MA, USA) was then added into each tube to dissolve the RNA pellet. Total RNA was subjected to a SpectraMax QuickDrop Micro-Volume Spectrophotometer (Molecular Devices, San Jose, CA, USA) for quality and quantity inspection. To avoid genomic DNA (gDNA) contamination, RNA samples were treated with DNase using the iScript gDNA Clear cDNA Synthesis Kit (Bio-Rad, Hercules, CA, USA) following the manufacturer's instructions. Subsequently, DNase-treated RNA was reverse transcribed using the iScript Reverse Transcription Supermix. The reaction program was set as $25^{\circ} \mathrm{C}$ for $5 \mathrm{~min}$, followed by a $20 \mathrm{~min}$ incubation at $46^{\circ} \mathrm{C}$. Finally, the reaction was terminated at $95^{\circ} \mathrm{C}$ for $1 \mathrm{~min}$. cDNA samples were then diluted 10 times with nuclease-free water.

The expression of elongation factor- $1 \alpha(E F-1 \alpha)$, lysozyme ( $L y z)$, superoxide dismutase (SOD), glutathione peroxidase (GPO), proPO I, proPO II, penaeidin 2-4 (Pen2, Pen3 and Pen4), peroxinectin $(P X)$, alpha-2-macroglobulin $(A 2 M)$, crustin $(C r u)$, and clotting protein $(C P)$ genes were detected using the primers listed in Table 1 . The qPCR reactions $(20 \mu \mathrm{L})$ consisted of $4 \mu \mathrm{L}$ cDNA, $10 \mu \mathrm{L}$ of RealQ Plus $2 \times$ Master Mix (Ampliqon A/S, Odense $\mathrm{M}$, Odense, Denmark), $2 \mu \mathrm{L}$ primer ( $1 \mu \mathrm{L}$ each for forward and reverse primer), and $4 \mu \mathrm{L}$ of nuclease-free water. The qPCR was performed using a StepOnePlus Real-Time PCR machine (Thermo Fisher Scientific). The cycling protocol was one cycle of initial denature at $95^{\circ} \mathrm{C}$ for $30 \mathrm{~s}$, followed by 40 cycles at $95^{\circ} \mathrm{C}$ for $15 \mathrm{~s}$ and $60^{\circ} \mathrm{C}$ for $1 \mathrm{~min}$. Melting curves were analyzed using the StepOne software. The transcript levels of the genes of interest were normalized to the expression of $E F-1 \alpha$ and presented as the fold change relative to the corresponding control group at each time point.

Table 1. Primers used in this study.

\begin{tabular}{|c|c|c|}
\hline Gene & Sequence $5^{\prime}-3^{\prime}$ & Reference \\
\hline $\begin{array}{c}\text { Lipopolysaccharide and } \beta \text {-1,3-glucan } \\
\text { binding protein }(L G B P)\end{array}$ & $\begin{array}{l}\text { CGGCAACCAGTACGGAGGAAC } \\
\text { GTGGAAATCATCGGCGAAGGAG }\end{array}$ & (Cheng et al., 2005) [34] \\
\hline Peroxinectin $(P X)$ & $\begin{array}{c}\text { ATCCAGCAGCCAGGTATG } \\
\text { CAGACTCATCAGATCCATTCC }\end{array}$ & (Liu et al., 2004) [35] \\
\hline Prophenoloxidase I (proPO I) & $\begin{array}{c}\text { ACGTCACTTCCGGCAAGCGA } \\
\text { CCTCCTTGTGAGCGTTGTCAGG }\end{array}$ & \\
\hline Prophenoloxidase II (proPO II) & $\begin{array}{c}\text { ACCACTGGCACTGGCACCTCGTCTA } \\
\text { TCGCCAGTTCTCGAGCTTCTGCAC }\end{array}$ & (Chen et al., 2014) [36] \\
\hline$\alpha 2$-macroglobulin $(A 2 M)$ & $\begin{array}{l}\text { GCACGTAATCAAGATCCG } \\
\text { CCCATCTCATTAGCACAAAC }\end{array}$ & \\
\hline
\end{tabular}


Table 1. Cont.

\begin{tabular}{|c|c|c|}
\hline Gene & Sequence $5^{\prime}-3^{\prime}$ & Reference \\
\hline \multirow{2}{*}{ Anti-lipopolysaccharide factor $(A L F)$} & CTGTGGAGGAACGAGGAGAC & \multirow{18}{*}{ (Wang et al., 2010) [37] } \\
\hline & CCACCGCTTAGCATCTTGTT & \\
\hline \multirow{2}{*}{ Crustin $(\mathrm{Cru})$} & GAGGGTCAAGCCTACTGCTG & \\
\hline & ACTTATCGAGGCCAGCACAC & \\
\hline \multirow{2}{*}{ Penaeidin 2 (Pen2) } & TCGTGGTCTGCCTGGTCTT & \\
\hline & CAGGTCTGAACGGTGGTCTTC & \\
\hline \multirow{2}{*}{ Penaeidin 3 (Pen3) } & CACCCTTCGTGAGACCTTTG & \\
\hline & AATATCCСTTTCCCACGTGAC & \\
\hline \multirow{2}{*}{ Penaeidin 4 (Pen4) } & GCCCGTTACCCAAACCATC & \\
\hline & CCGTATCTGAAGCAGCAAAGTC & \\
\hline \multirow{2}{*}{ Lysozyme (Lyz) } & GAAGCGACTACGGCAAGAAC & \\
\hline & AACCGTGAGACCAGCACTCT & \\
\hline \multirow{2}{*}{ Superoxidase dismutase (SOD) } & ATCCACCACACAAAGCATCA & \\
\hline & AGCTCTCGTCAATGGCTTGT & \\
\hline \multirow{2}{*}{ Glutathione peroxidase (GPO) } & TTTTTCCGTGCAAAAAGGAC & \\
\hline & TAATACGCGATGCCCCTAAC & \\
\hline \multirow{2}{*}{ Clotting protein $(C P)$} & TCTTTGCGCAGTTGGTGATC & \\
\hline & TGAGGTGACCGAGTGCAAAA & \\
\hline & ATGGTTGTCAACTTTGCCCC & \multirow{2}{*}{ (Chen et al., 2014) [36] } \\
\hline Elongation factor $1 \alpha(E F T \alpha)$ & TTGACCTCCTTGATCACACC & \\
\hline
\end{tabular}

\subsection{In Vivo Experimental Design}

Different concentrations of PE were diluted with SSS buffer before being injected. Twelve whiteleg shrimps $(7.0 \pm 0.4 \mathrm{~g}$ in weight) were anesthetized using Eugenol $(50 \mathrm{mg} / \mathrm{L})$ (HiMedia Laboratories, Mumbai, India) and injected with 0, 0.08, 0.15, and $0.30 \mu \mathrm{g}$ PE/g body weight, respectively. The in vivo imaging system (IVIS) Lumina LT series III (Caliper, MA, USA) was used to determine the fluorescence intensities of the PE in the shrimp at $2,4,6$, and $8 \mathrm{~h}$ post-injection through image processing using the appropriate excitation and emission filters [38]. The background signal was subtracted from the two-dimensional images, and the image scaling was established by transforming total radiance efficiency. Fluorescence intensity was described by a multicolor scale ranging from blue (least intense) to red (most intense). Signal intensity figures were superimposed over grayscale reference pictures for anatomical denotation. Scales were set manually to the same values for comparable images to normalize the intensity of the fluorescence across time points. The fluorescence intensity of a specific area of individual samples was measured using the region of interest (ROI) tool in the Live Image 4.5 software (PerkinElmer, Waltham, MA, USA).

\subsection{Challenge Test}

To determine the susceptibility of L. vannamei to V. parahaemolyticus and WSSV after PE treatment, PE solution was injected into the ventral sinus of the cephalothorax of individual L. vannamei $(7.0 \pm 0.4 \mathrm{~g}$ in weight) to achieve doses of $0.08,0.15$, and $0.30 \mu \mathrm{g} \mathrm{PE} / \mathrm{g}$ body weight. The challenge test was conducted by injecting $10 \mu \mathrm{L}$ of bacterial suspension $\left(1 \times 10^{8}\right.$ colony forming units $\left.(\mathrm{CFU}) / \mathrm{mL}\right)$ resulting in $1 \times 10^{6} \mathrm{CFU} /$ whiteleg shrimp and $9.19 \times 10^{4}$ copies/whiteleg shrimp of WSSV through the ventral sinus of the cephalothorax $24 \mathrm{~h}$ after the PE injection. Shrimp that did not receive PE treatment but received the same doses of V. parahaemolyticus and WSSV served as the challenge controls. Whiteleg shrimp that received an injection of SSS buffer without either infectious agent served as the unchallenged controls. A total of 110 whiteleg shrimp (10 groups $\times 11$ whiteleg shrimp) were used in this experiment and whiteleg shrimp survival was observed at 12, 24, 36, 48,60 , and $72 \mathrm{~h}$ post-challenge. Continuous aeration was provided for each aquarium and $75 \%$ of the water was changed every day to remove the impurities and to assure the maintenance of water quality. 


\subsection{Statistical Analysis}

The expression of the gene of interest was first normalized to the expression level of housekeeping gene $(E F-1 \alpha)$. The ratio was then scaled and log2-transformed to improve the normality of the data prior to statistical analysis [39]. A paired sample $t$-test was performed to compare gene expression levels between treatment and control groups with a $p$-value less than 0.05 considered significant. One-way analysis of variance (ANOVA) with Tukey's post hoc test in the IBM SPSS Statistics Package 22.0 (SPSS Inc., Chicago, IL, USA) was conducted for comparison of the difference between the treatment and control groups in ROS production, PO activity, and phagocytic activity, with a $p$-value less than 0.05 considered significant.

\section{Results}

\subsection{Purification of Phycoerythrin}

An extract of phycobiliproteins was obtained from Colaconema sp. and further saturated with ammonium sulfate prior to being applied to a gel filtration column. The purity of the PE from the alga was examined by calculating the ratio of each pigment from the purified PE as well as the purity index. As shown in Table 2, PE, APC, and PC accounted for $93.6 \%, 4.54 \%$, and $1.8 \%$ of the purified proteins, with the purity index at 4.31 for PE. The purified PE protein had a size of $150 \mathrm{kDa}$ in the native PAGE analysis, similar to that of commercial PE (Figure 1A). The subunit components of this fraction were analyzed by SDS-PAGE. There were two bands between 15 and $20 \mathrm{kDa}$, and a lighter band at $30 \mathrm{kDa}$ (Figure 1B). We compared the purity of Colaconema sp. PE to the commercial PE (standard). Our result showed that in 6.5-8 min retention time, the fluorescence emission from the PE extracted in the present study and the commercial standard PE described the same curve (Figure 2). Meanwhile, the light intensity of the PE purified from Colaconema sp. increased in a linear dose-dependent manner (Figure 3). Interestingly, at the same concentration, we noticed higher fluorescence intensity in our purified PE than in the commercial PE (Figure 4).

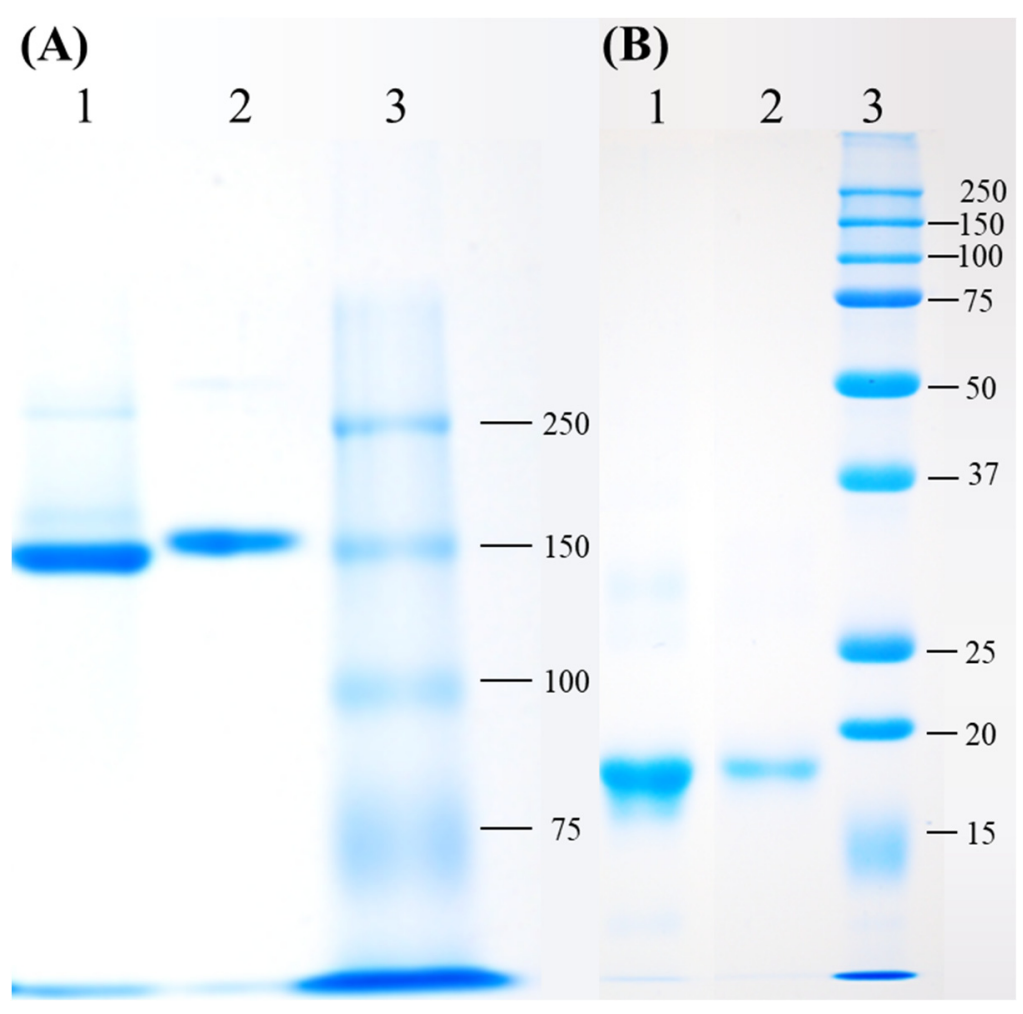

Figure 1. Detection of the purified phycoerythrin (PE) of Colaconema sp. via (A) native PAGE and (B) SDS-PAGE. Native and SDS gels electrophoresis were run in $8 \%$ and $15 \%$ gel, respectively. (A) Native 
PAGE result. Lane 1, purified PE of Colaconema sp.; Lane 2, Standard-PE; Lane 3, protein molecular mass marker. The apparent molecular weight of Colaconema sp. was $150 \mathrm{kDa}$, similar to the standardPE. (B) SDS-PAGE result. Lane 1, purified PE of Colaconema sp.; Lane 2, standard-PE; Lane 3, protein molecular mass marker. The apparent molecular weight of Colaconema sp. was 15-20 kDa, similar to the standard-PE. The protein in each lane was loaded $5 \mu \mathrm{g}$.

Table 2. The ratio in phycoerythrin (PE), allophycocyanin (APC), and phycocyanin (PC) concentration of purified pigments of Colaconema sp.

\begin{tabular}{cccc}
\hline Pigments Source & Phycoerythrin & Allophycocyanin & Phycocyanin \\
\hline Colaconema sp. & $93.6 \%$ & $4.54 \%$ & $1.8 \%$ \\
\hline
\end{tabular}

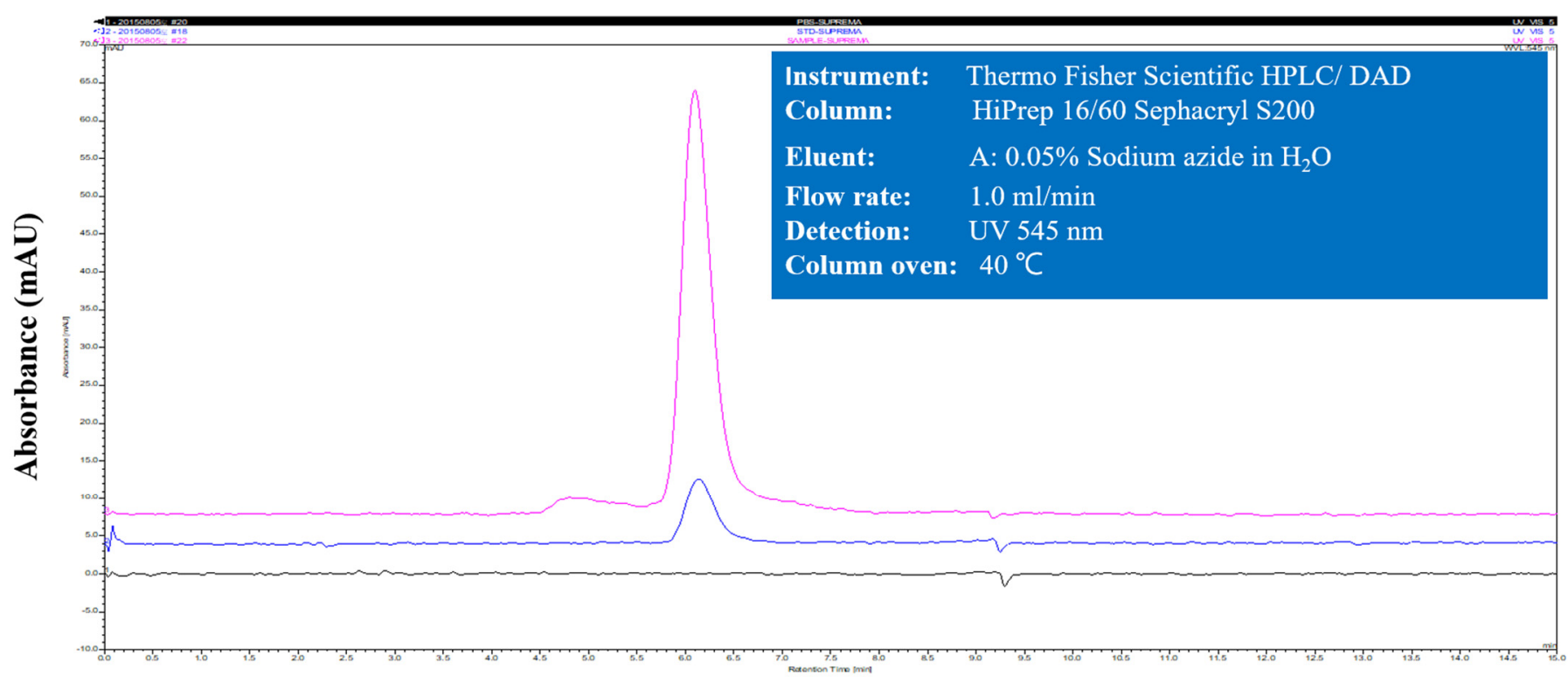

\section{Retention time (min)}

Figure 2. Absorption spectrum of phycoerythrin (PE) purified by size exclusion chromatography in HPLC using a HiPrep Sephacryl S-300 HR column (Pink line: Colaconema sp.-PE; blue line: standard-PE; black line: PBS buffer).

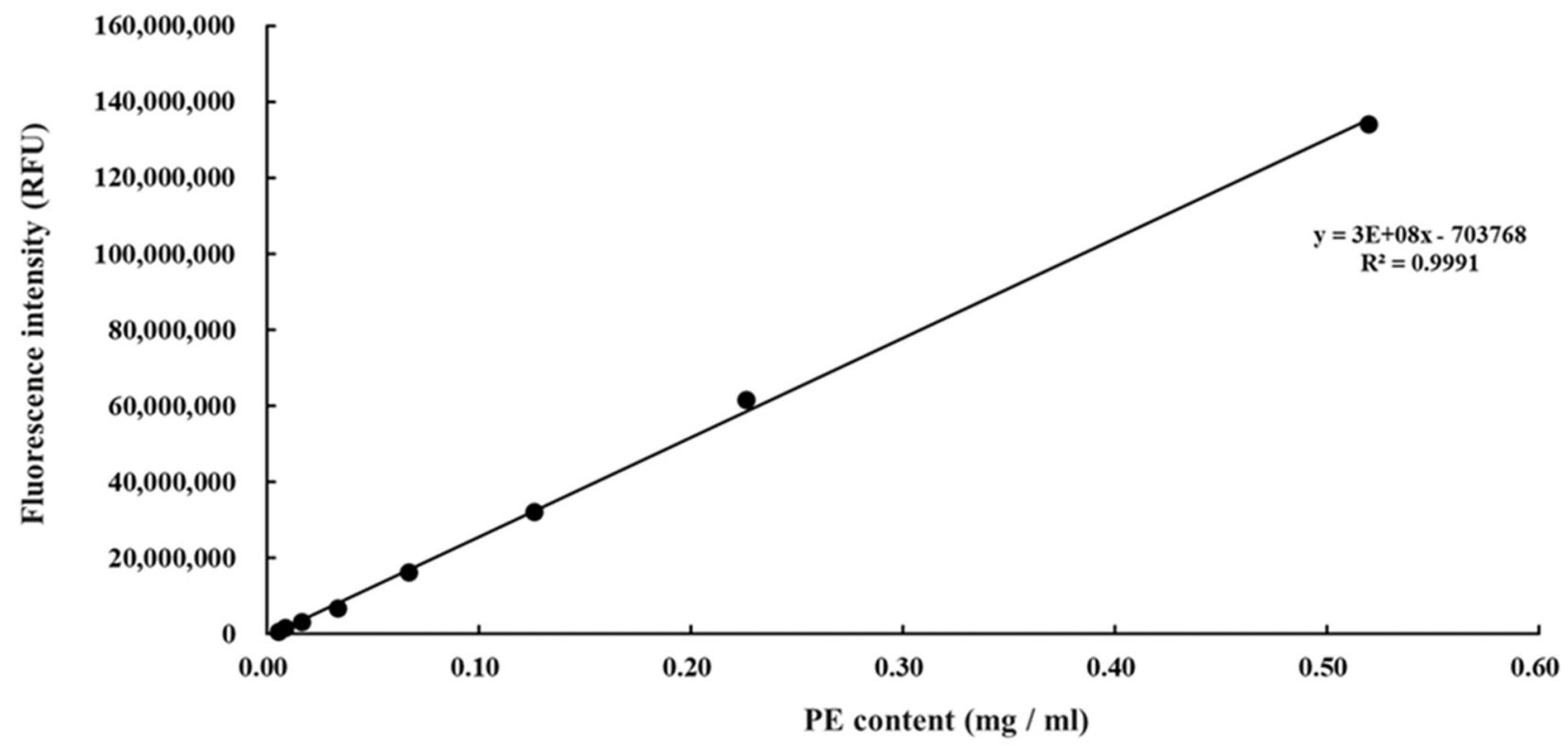

Figure 3. Detection of the fluorescence intensity and phycoerythrin (PE) concentration purified from Colaconema sp. 


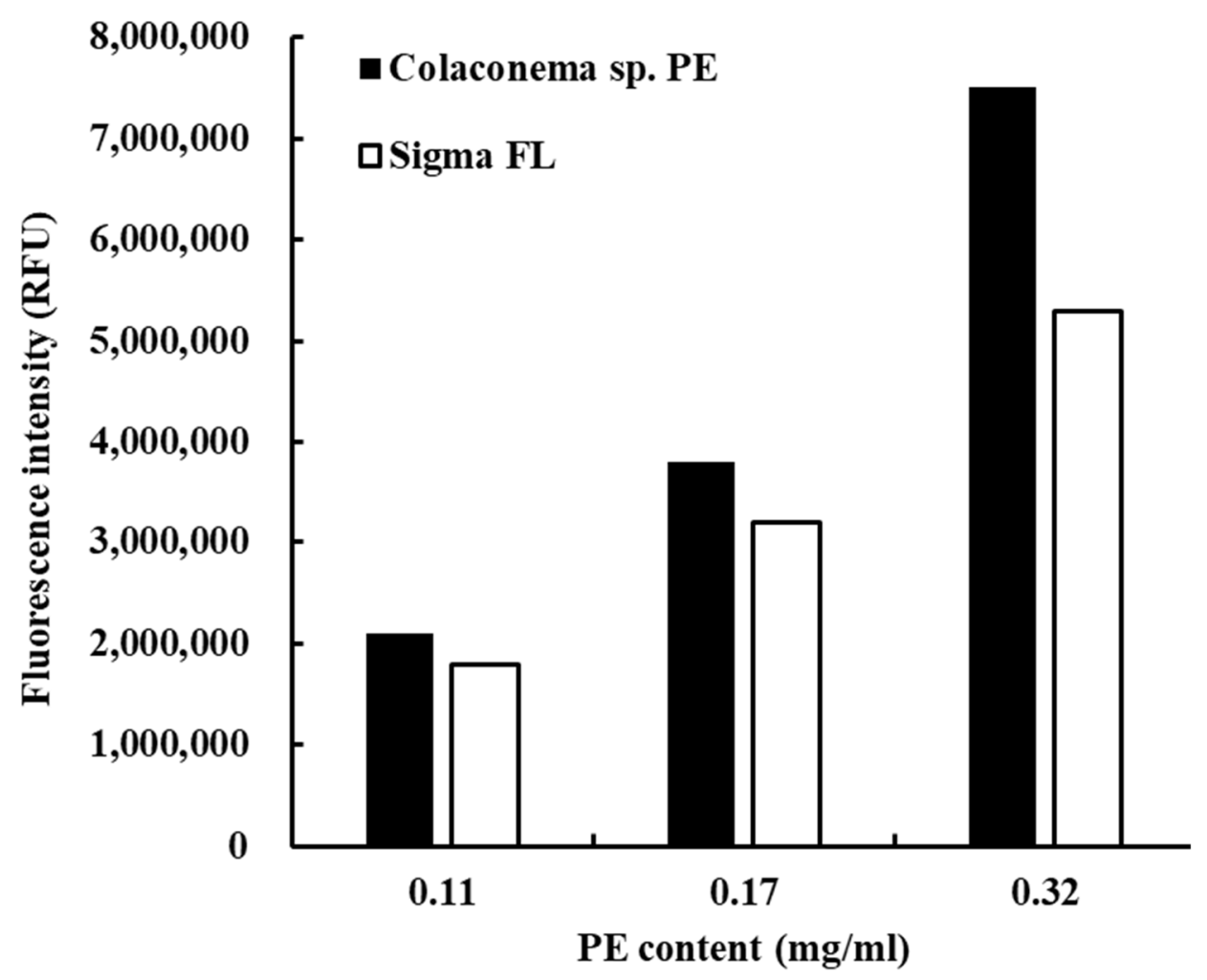

Figure 4. Comparison of the fluorescence intensity of phycoerythrin (PE) purified from Colaconema sp. and commercial standard PE (Sigma FL52412) at different concentrations (0.011, 0.017, and $0.032 \mathrm{mg} / \mathrm{mL}$ ).

\subsection{In Vitro Effects of PE on Innate Immune Parameters in Hemocytes}

The effects of the different PE doses on whiteleg shrimp phenoloxidase (PO) activity, ROS, and phagocytosis activity are shown in Figure 5. Compared to the control group, the $\mathrm{PO}$ and phagocytosis activity of the hemocytes treated with PE were upregulated in a dose-dependent manner ( $p<0.05$; Figure $5 \mathrm{~A}, \mathrm{C})$. On the other hand, the ROS production rate was gradually inhibited when hemocytes were treated with increasing doses of $\mathrm{PE}$ (Figure 5B).

\subsection{Observation Using an In Vivo Imaging System after PE Injection}

The visualization of different doses of PE injected into whiteleg shrimp was conducted using an IVIS at $2 \mathrm{~h}, 4 \mathrm{~h}, 6 \mathrm{~h}$, and $8 \mathrm{~h}$ post-injection. The PE content inside the whiteleg shrimp body was directly related to the injection dose. The signal was observed in the cephalothorax where the PE was injected and gradually diffused to the abdomen and dorsal part of the whiteleg shrimp body (Figure 6). 
(A)

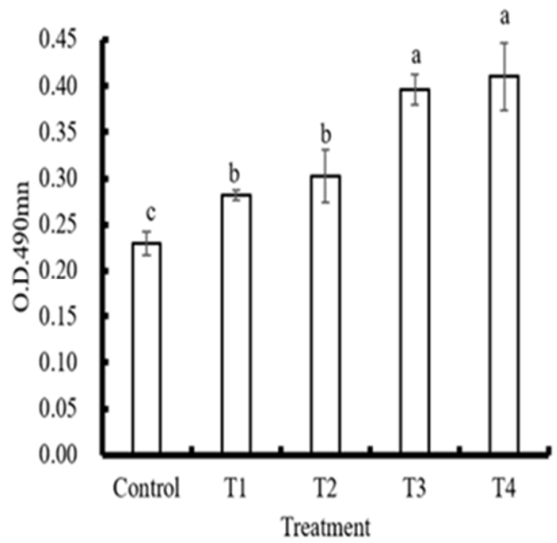

(B)

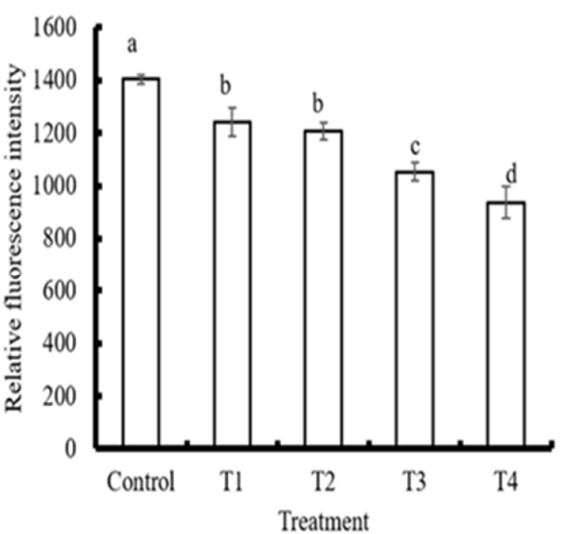

(C)

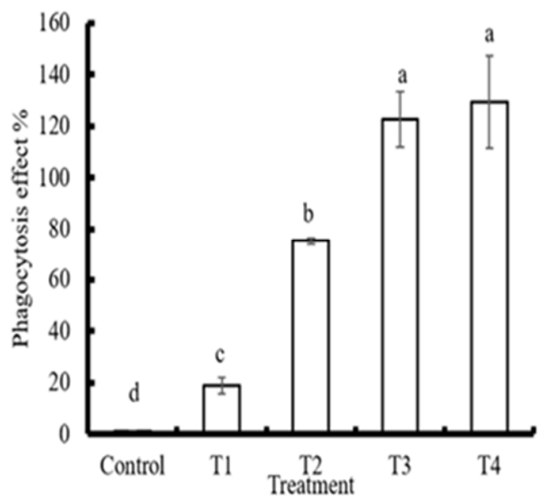

Figure 5. The effects of different phycoerythrin doses on the immune indices of hemocytes. The (A) prophenoloxidase activity, (B) reactive oxygen species production, and (C) phagocytosis activity in hemocytes of whiteleg shrimp (Litopenaeus vannamei) were examined after treating hemocytes with various doses of purified phycoerythrin $\left(T_{1}, T_{2}, T_{3}\right.$, and $T_{4}$ represent treatments of $8,14,27$, and $52 \mu \mathrm{g} / \mathrm{mL}$, respectively). Data are presented as the mean \pm standard error of mean $(n=5)$. Significant differences ( $p<0.05$, one-way ANOVA and Tukey's post hoc test) are expressed by different letters. O.D., optical density; RFU, relative fluorescence units.

(A)

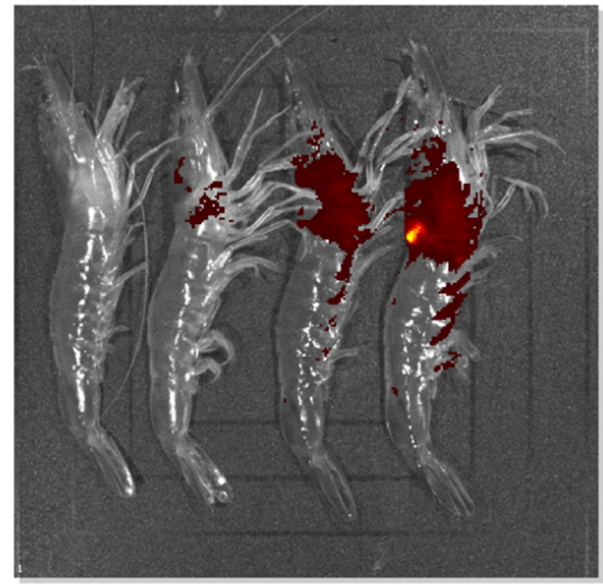

$$
\begin{array}{llll}
\mathbf{T}_{0} & \mathbf{T}_{1} & \mathbf{T}_{2} & \mathbf{T}_{3}
\end{array}
$$

(C)

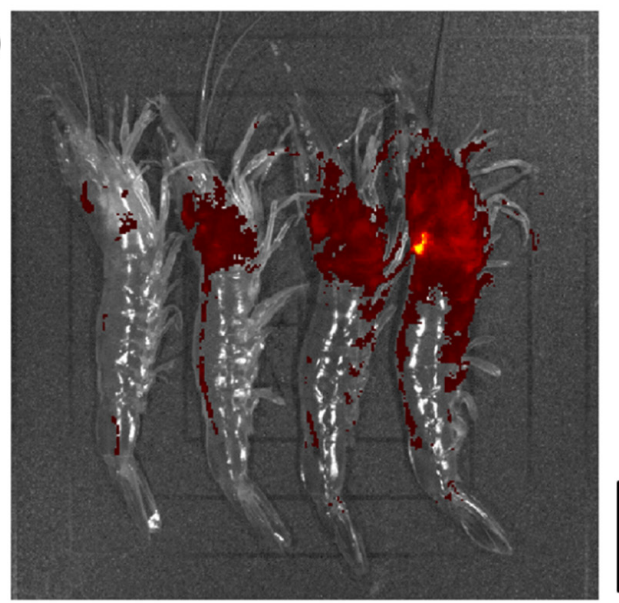

$\begin{array}{llll}\mathbf{T}_{0} & \mathbf{T}_{1} & \mathbf{T}_{2} & \mathbf{T}_{3}\end{array}$
(B)
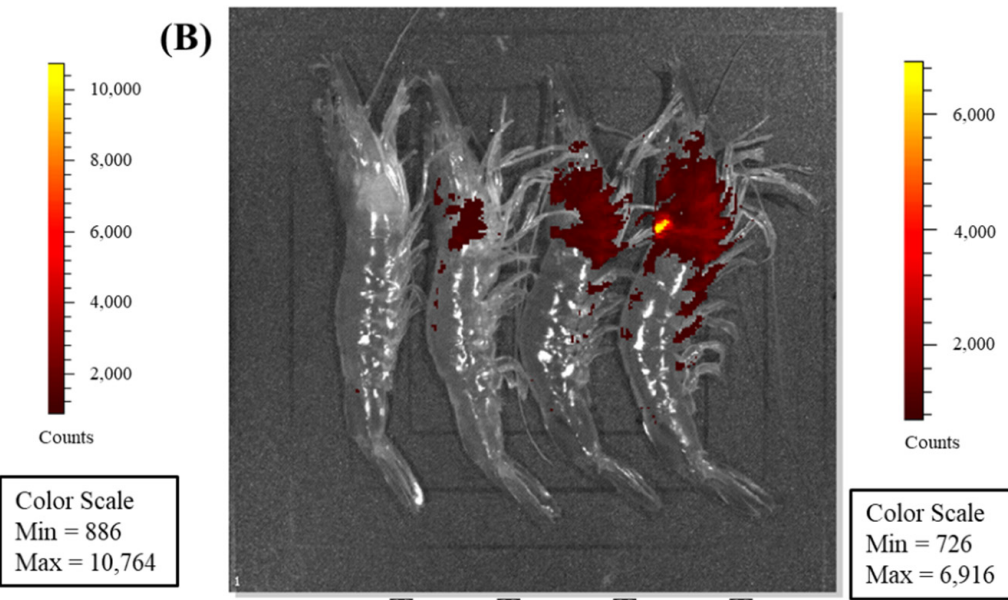

Color Scale Min $=726$ $\operatorname{Max}=6,916$

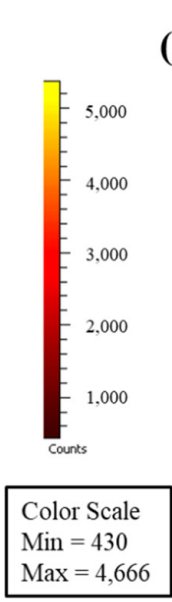

(D)

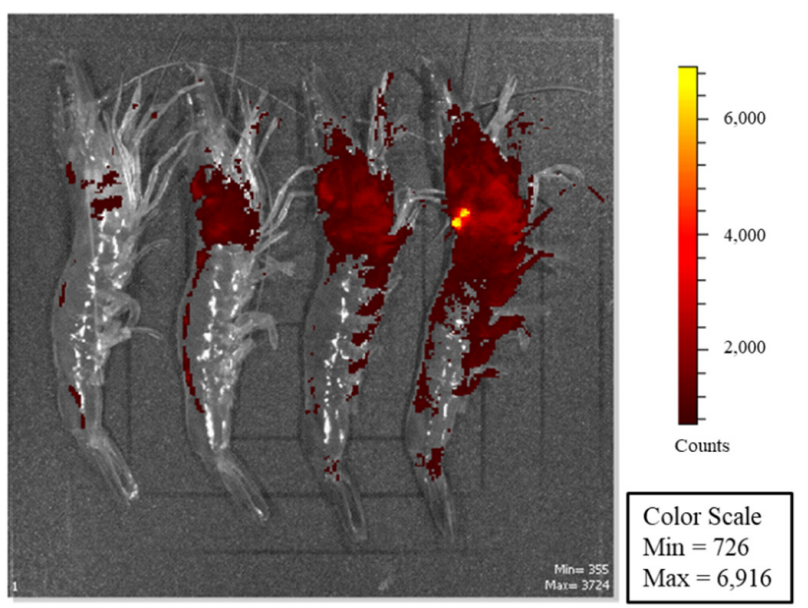

$\begin{array}{llll}\mathbf{T}_{0} & \mathbf{T}_{1} & \mathbf{T}_{2} & \mathbf{T}_{3}\end{array}$

Figure 6. Visualization of whiteleg shrimp after injections of different doses of phycoerythrin. The whiteleg shrimp were observed under an in vivo imaging system (IVIS) at 2 (A), 4 (B), 6 (C), and 8 (D) hours post-injection with 0, ( $\mathrm{T}_{0}$; control), $0.08\left(\mathrm{~T}_{1}\right), 0.15\left(\mathrm{~T}_{2}\right)$ and $0.30\left(\mathrm{~T}_{3}\right) \mu \mathrm{g}$ phycoerythrin per gram of whiteleg shrimp body weight. 


\subsection{Expression Analysis of Immune Genes}

At 8 and $24 \mathrm{~h}$ after injection with PE, whiteleg shrimp hemocyte RNA was isolated to detect the effects of $\mathrm{PE}$ on the immune response. Genes related to the proPO system ( $p P O I$ and $p P O I I$ ) were not upregulated by PE injection, and neither were $A 2 M$ or $P X$. However, $\mathrm{Cr} u$ expression was elevated $24 \mathrm{~h}$ post PE injection (Figure 7 ). The expression profiles of $C P$ and $S O D$ in hemocytes at both sampling times in the PE treated whiteleg shrimp were comparable to the control group (Figure $8 \mathrm{~A}, \mathrm{~B}$ ), but we noted a significant increase in $L Y Z$ expression (Figure 8C) and a non-significant induction of LGBP $24 \mathrm{~h}$ after PE treatment (Figure 8D). Similarly, the expression of GPO (Figure 9A) and PEN3 (Figure 9C) were marginally induced at $24 \mathrm{~h}$ post-PE injection, but at the same time point, the transcript levels of PEN4 and ALF were significantly higher in the group that received PE than the group injected with PBS (Figure 9D,E). The PEN2 transcript levels did not differ significantly between the control and experimental groups (Figure 9B).

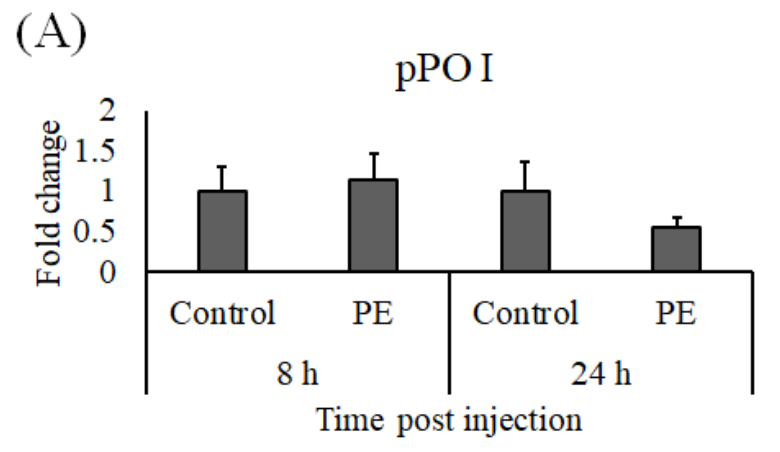

(C)

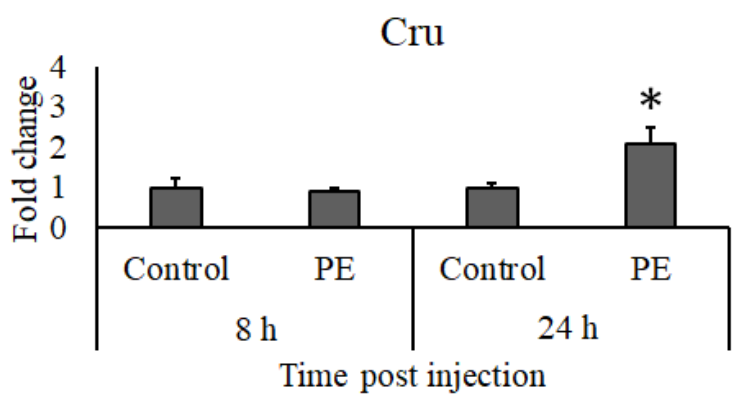

(E)

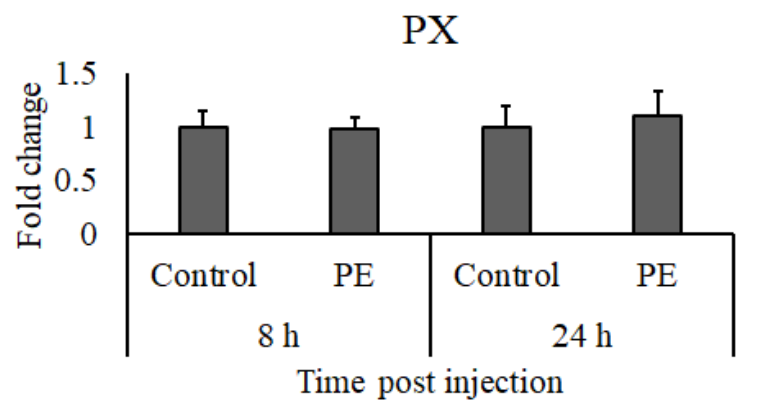

(B)

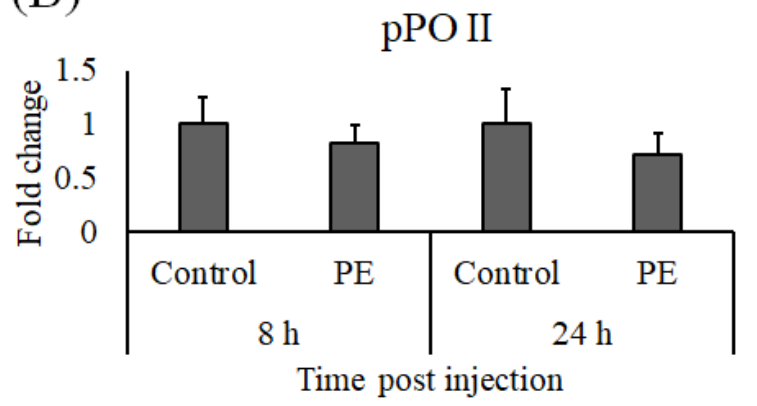

(D)

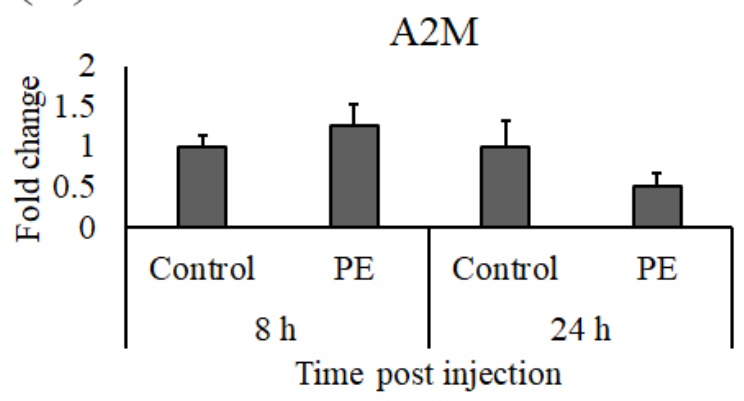

Figure 7. Gene expression of (A) proPO I, (B) proPO II, (C) Cru, (D) A2M, and (E) PX in hemocytes from whiteleg shrimp (Litopenaeus vannamei) injected with $0.30 \mu \mathrm{g}$ of phycoerythrin (PE) per gram of whiteleg shrimp body weight or vehicle alone (control). After 8 and $24 \mathrm{~h}$ of stimulation, the relative expression levels of immune genes were normalized to the transcript level of $E F 1 \alpha$ and presented as a fold change relative to the control group. Data are shown as the mean \pm standard error of the mean $(n=5)$ and significant differences from the control group are denoted by asterisks $(p<0.05$, paired sample $t$-test). 
(A)

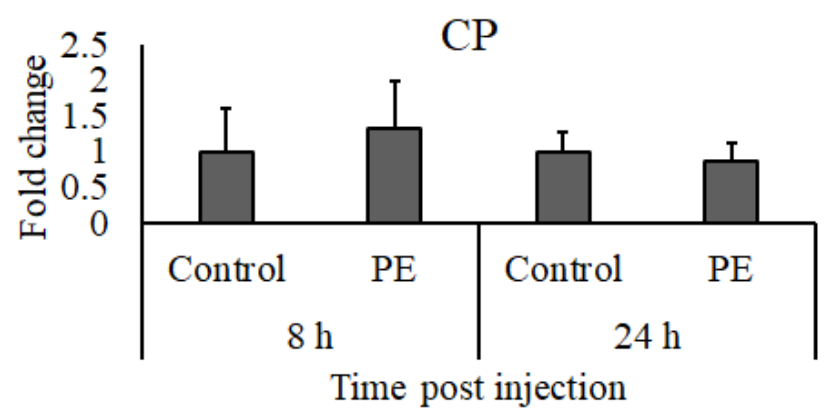

(C)

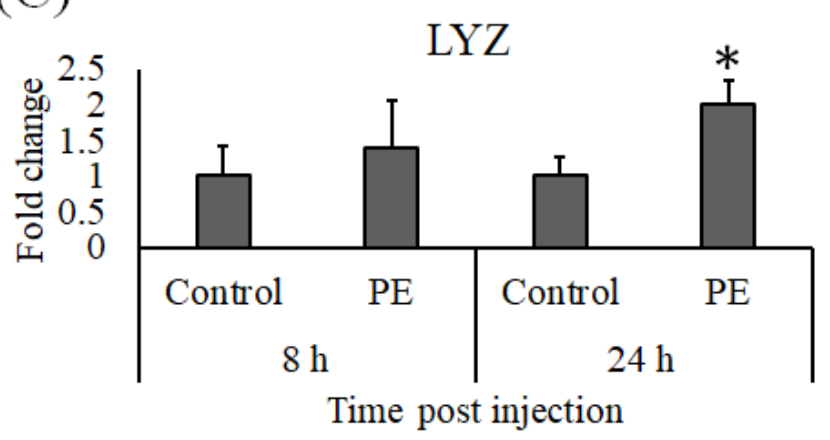

(B)

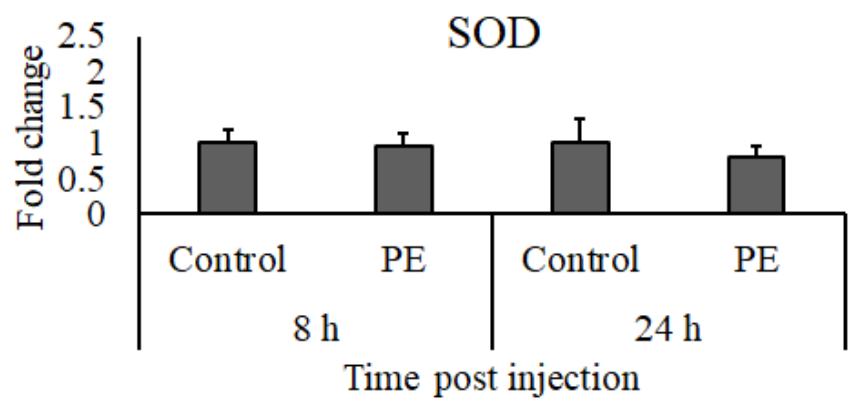

(D)

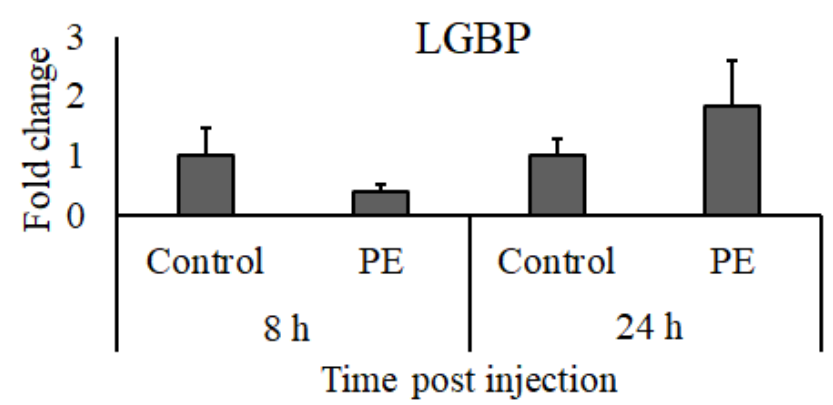

Figure 8. Gene expression of (A) CP, (B) SOD, (C) LYZ, and (D) LGBP in hemocytes from whiteleg shrimp (Litopenaeus vannamei) injected with $0.30 \mu \mathrm{g}$ of phycoerythrin (PE) per gram of whiteleg shrimp body weight or vehicle alone (control). After 8 and $24 \mathrm{~h}$ of stimulation, the relative expression levels of immune genes were normalized to the transcript level of EF1 $\alpha$ and presented as a fold change relative to the control group. Data are expressed as the mean \pm standard error of the mean $(n=5)$ and significant differences from the control group are denoted by asterisks $(p<0.05$, paired sample $t$-test).

\subsection{Challenge Trials}

3.5.1. Effects of PE on the Survival Rate of L. vannamei Challenged with $V$. parahaemolyticus

As shown in Figure 10, all unchallenged control whiteleg shrimp survived the experiment. However, death began to occur after $12 \mathrm{~h}$ in the V.parahaemolyticus-challenged whiteleg shrimp. During the period of observation, the survival rates of the whiteleg shrimp that received different doses of PE $(0.08,0.15$, and $0.30 \mu \mathrm{g} / \mathrm{g}$ body weight $)$ were always higher than those of the whiteleg shrimp that did not receive PE but were challenged with $V$. parahaemolyticus. The survival rates for whiteleg shrimp that received $0.08,0.15$, and $0.30 \mu \mathrm{g} \mathrm{PE} / \mathrm{g}$ body weight prior to the bacterial challenge were $27.27 \%, 54.55 \%$, and $63.64 \%$, respectively, $72 \mathrm{~h}$ post-challenge, while the survival rate was only $18.2 \%$ for the challenged control group. The survival rate of whiteleg shrimp was significantly higher in the group that received $0.30 \mu \mathrm{g} \mathrm{PE} / \mathrm{g}$ body weight than the untreated control group after exposure to $V$. parahaemolyticus. 
(A)

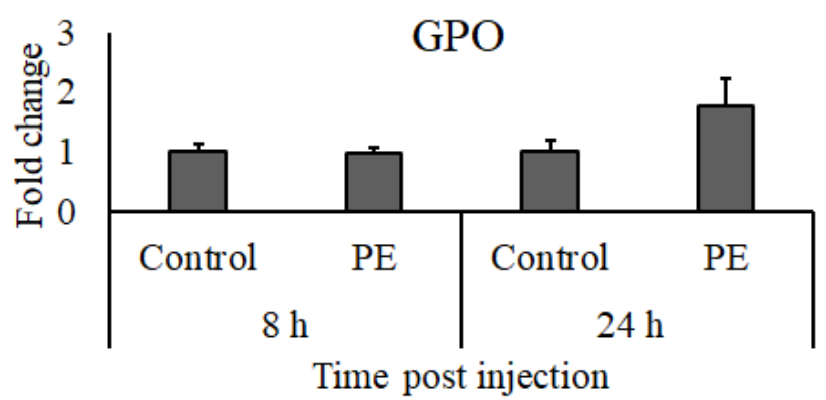

(C)

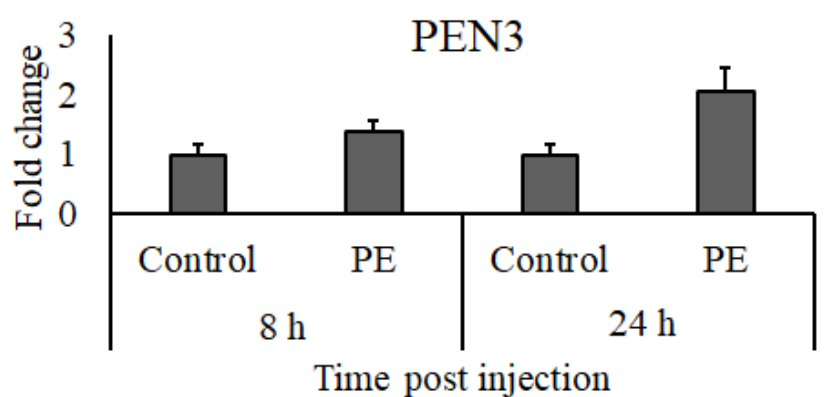

(E)

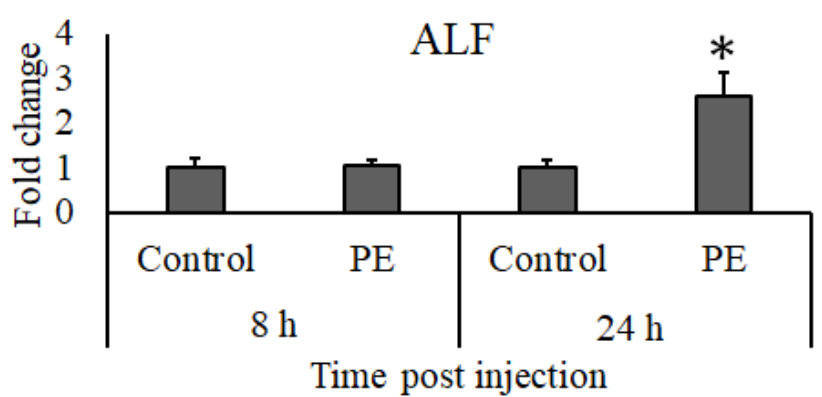

(B)

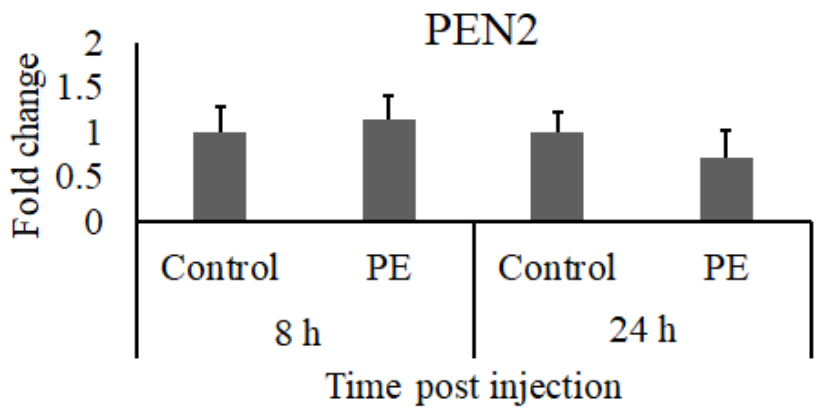

(D)

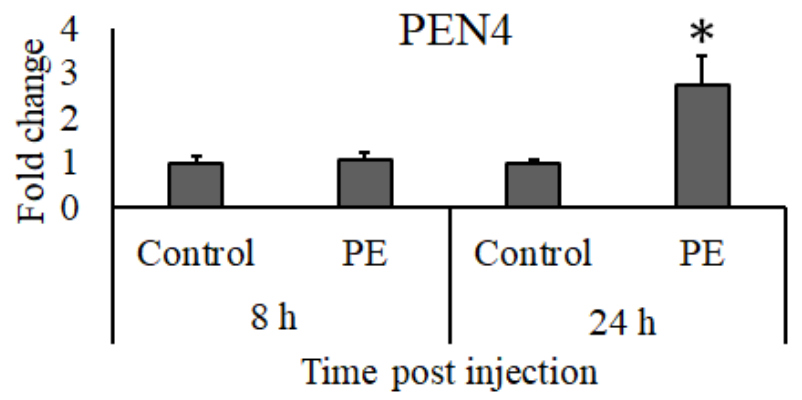

Figure 9. Gene expression of (A) GPO, (B) PEN2, (C) PEN3, (D) PEN4 and (E) ALF in hemocytes from whiteleg shrimp (Litopenaeus vannamei) injected with $0.30 \mu \mathrm{g}$ of phycoerythrin (PE) per gram of whiteleg shrimp body weight or vehicle alone (control). After 8 and $24 \mathrm{~h}$ of stimulation, the relative expression levels of immune genes were normalized to the transcript level of EF1 $\alpha$ and presented as a fold change relative to the control group. Data are expressed as the mean \pm standard error of the mean $(n=5)$ and significant differences from the control group are denoted by asterisks $(p<0.05$, paired sample $t$-test). 
3.5.2. Effects of PE on the Survival Rate of L. vannamei Challenged with White Spot Syndrome Virus

In the WSSV challenge trial, death began to occur after $36 \mathrm{~h}$. The survival rates of whiteleg shrimp that received with PE at 0.15 and $0.30 \mu \mathrm{g} / \mathrm{g}$ body weight were insignificantly higher than the survival rate of challenged control whiteleg shrimp $72 \mathrm{~h}$ post-challenge (Figure 11). The survival rate at $72 \mathrm{~h}$ was $0 \%, 27.3 \%$, and $36.4 \%$ for whiteleg shrimp that had been injected with low, medium, and high doses of PE, respectively, before being treated with WSSV, while no whiteleg shrimp survived in the challenged control group at the end of the observation period. All unchallenged control whiteleg shrimp survived over the experimental period.

(A)

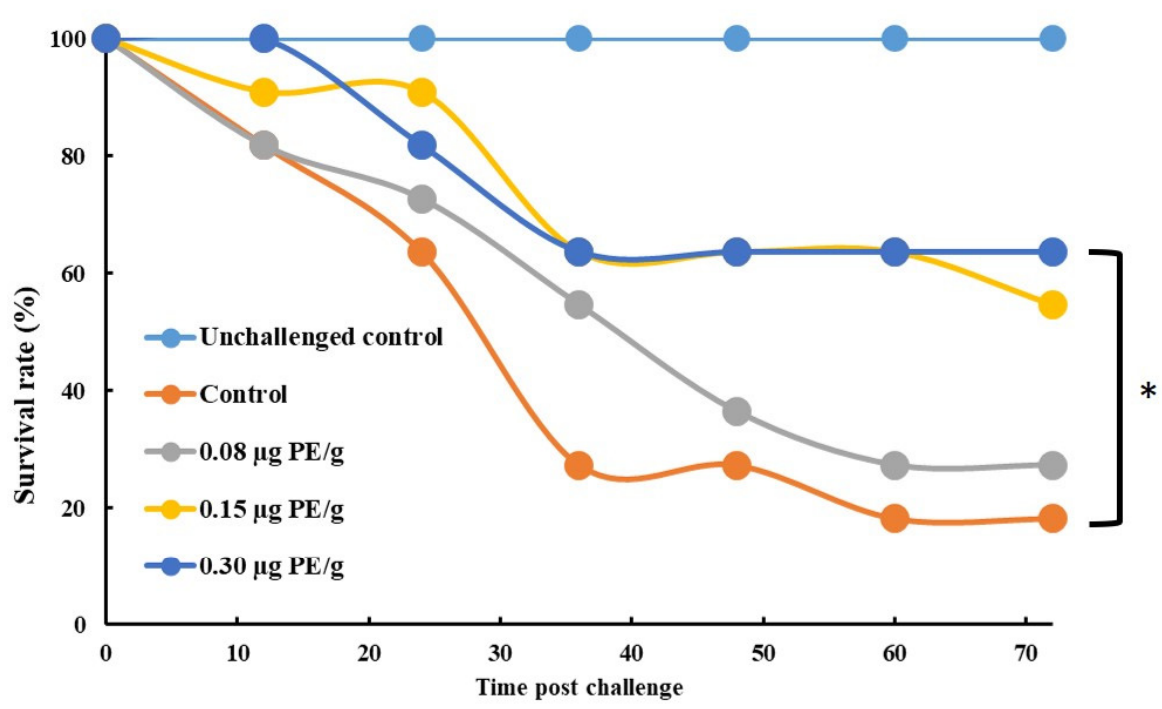

(B)

\begin{tabular}{|c|c|c|c|c|c|c|c|c|c|c|c|}
\hline \multirow[b]{2}{*}{ Group } & & \multicolumn{2}{|c|}{ Control } & \multicolumn{2}{|c|}{$0.08 \mu \mathrm{g} \mathrm{PE} / \mathrm{g}$} & \multicolumn{2}{|c|}{$0.15 \mu \mathrm{g} \mathrm{PE} / \mathrm{g}$} & \multicolumn{2}{|c|}{$0.30 \mu \mathrm{g} P E / \mathrm{g}$} & \multicolumn{2}{|c|}{ Unchallenged Con. } \\
\hline & & Chi-Square & Sig. & Chi-Square & Sig. & Chi-Square & Sig. & Chi-Square & Sig. & Chi-Square & Sig. \\
\hline Log Rank (Mantel & Control & & & 0.318 & 0.573 & 3.823 & 0.051 & 4.283 & 0.038 & 14.982 & 0.000 \\
\hline \multirow{4}{*}{ Cox) } & $0.08 \mu \mathrm{g} \mathrm{PE} / \mathrm{g}$ & 0.318 & 0.573 & & & 1.955 & 0.162 & 2.485 & 0.115 & 12.422 & 0.000 \\
\hline & $0.15 \mu \mathrm{g} P E / \mathrm{g}$ & 3.823 & 0.051 & 1.955 & 0.162 & & & 0.089 & 0.765 & 6.197 & 0.013 \\
\hline & $0.30 \mu \mathrm{g} P E / \mathrm{g}$ & 4.283 & 0.038 & 2.485 & 0.115 & 0.089 & 0.765 & & & 4.666 & 0.031 \\
\hline & Unchallenged & 14.982 & 0.000 & 12.422 & 0.000 & 6.197 & 0.013 & 4.666 & 0.031 & & \\
\hline
\end{tabular}

Figure 10. Effects of phycoerythrin (PE) on the survival rate of whiteleg shrimp (Litopenaeus vannamei) challenged with Vibrio parahaemolyticus during $72 \mathrm{~h}$. The unchallenged control treatment was injected only with whiteleg shrimp saline solution (SSS), while other groups received SSS buffer containing $0,0.30,0.15$, and $0.08 \mu \mathrm{g}$ of PE per gram of body weight prior to be challenged with Vibrio parahaemolyticus $\left(1 \times 10^{6} \mathrm{CFU}\right.$ per shrimp). (A) Survivorship curves for whiteleg shrimp after challenged by $V$. parahaemolyticus. (B) Differences among the groups were assessed using the Mantel-Cox test for pairwise comparisons. Significant differences $(p<0.05)$ are indicated by asterisks. 
(A)

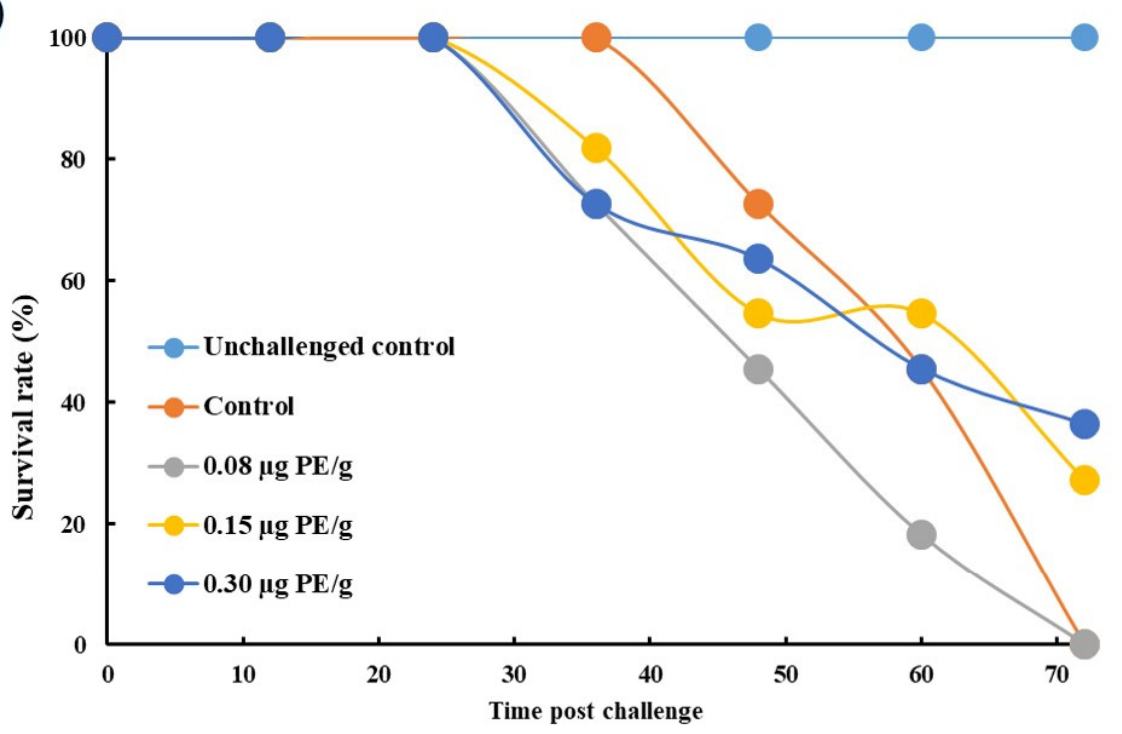

(B)

\begin{tabular}{|c|c|c|c|c|c|c|c|c|c|c|c|}
\hline \multicolumn{12}{|c|}{ Pairwise Comparisons } \\
\hline \multirow[b]{2}{*}{ Group } & & \multicolumn{2}{|c|}{ Control } & \multicolumn{2}{|c|}{$0.08 \mu \mathrm{g} \mathrm{PE} / \mathrm{g}$} & \multicolumn{2}{|c|}{$0.15 \mu \mathrm{g} \mathrm{PE} / \mathrm{g}$} & \multicolumn{2}{|c|}{$0.30 \mu \mathrm{g} \mathrm{PE} / \mathrm{g}$} & \multicolumn{2}{|c|}{ Unchallenged Con. } \\
\hline & & Chi-Square & Sig. & Chi-Square & Sig. & Chi-Square & Sig. & Chi-Square & Sig. & Chi-Square & Sig. \\
\hline Log Rank (Mantel- & Control & & & 2.773 & 0.096 & 0.024 & 0.877 & 0.756 & 0.385 & 21.049 & 0.000 \\
\hline Cox) & $0.08 \mu \mathrm{g} \mathrm{PE} / \mathrm{g}$ & 2.773 & 0.096 & & & 0.844 & 0.358 & 2.996 & 0.083 & 22.994 & 0.000 \\
\hline & $0.15 \mu \mathrm{g} \mathrm{PE} / \mathrm{g}$ & 0.024 & 0.877 & 0.844 & 0.358 & & & 0.248 & 0.619 & 11.774 & 0.001 \\
\hline & $0.30 \mu \mathrm{g} \mathrm{PE} / \mathrm{g}$ & 0.756 & 0.385 & 2.996 & 0.083 & 0.248 & 0.619 & & & 10.040 & 0.002 \\
\hline & Unchallenged & 21.049 & 0.000 & 22.994 & 0.000 & 11.774 & 0.001 & 10.040 & 0.002 & & \\
\hline
\end{tabular}

Figure 11. Effects of phycoerythrin (PE) $(0,0.30,0.15$, and $0.08 \mu \mathrm{g} / \mathrm{g}$ body weight) on the survival rate of whiteleg shrimp (Litopenaeus vannamei) challenged with whiteleg spot syndrome virus (WSSV) during $72 \mathrm{~h}$. The unchallenged control treatment was injected only with whiteleg shrimp saline solution (SSS), while other groups received SSS buffer containing 0 , $0.30,0.15$, and $0.08 \mu \mathrm{g}$ of PE per gram of body weight prior to be challenged with WSSV $\left(9.19 \times 10^{4}\right.$ copies per shrimp). (A) Survivorship curves for whiteleg shrimp after challenged by WSSV. (B) Differences among the groups were assessed using the Mantel-Cox test for pairwise comparisons.

\section{Discussion}

Whiteleg shrimp is a crucial food source; its cultural industry plays a key role in human development. Previous studies have demonstrated that multiple terrestrial and marine herbs extract can improve whiteleg shrimp immunity to resist pathogens [40-42]. The potential immunomodulatory activity functions of algal PE in mammals have been reported in a previous study [43], but as far as we know, it has not previously been investigated in whiteleg shrimp immunity. Therefore, in this study, we extracted PE from Colaconema sp. and tested its effects on whiteleg shrimp immunity.

The proteins extracted and purified from Colaconema sp. had PE as a major component $(93.6 \%)$ and the molecular weight of PE was verified via gel electrophoresis analysis. A similar molecular weight ( 150 kDa) as the commercial standard PE was observed in the native PAGE analysis; however, three bands, instead of the one band expected from the commercial standard PE, were seen in the PE extracted from Colaconema sp. when analyzed in SDS-PAGE, suggesting that the PE in Colaconema sp. is composed of $\alpha \beta \gamma$ subunits, with the most prominent signal between 15 and $20 \mathrm{kDa}$ (Figure 1). Similar results were reported for PE isolated from Porphyridium cruentum [44], Porphyra yezoensis [45], and Portieria hornemannii [46]. We thus conclude that the PE purified in this study has the same subunits as reported in PE sourced from other red algae. 
Hemocytes use phagocytosis to directly internalize pathogenic microbes in phagosomes and destroy them using degradative enzymes (e.g., lysozymes) and ROS [47], which are known to destroy bio-macromolecules (e.g., DNA, RNA, proteins, and lipids) through oxidation reactions [48,49]. To avoid excessive ROS that may harm the host itself, SOD is generated to reduce the excessive superoxide anions by transforming them into hydrogen peroxide, to be later degraded by GPO or catalase [50]. ROS production was significantly decreased by PE treatment in vitro (Figure 4), indicating that PE has an anti-oxidation ability that can protect the host from damage by over-enhanced immune responses [51]. Similarly, the expression of SOD and GPO was not triggered in hemocytes from PE-injected whiteleg shrimp, supporting the notion that PE treatment would not induce (or rather, it would reduce) ROS production; therefore, hemocytes do not need to increase expression of these two antioxidant genes for the conversion of ROS into less toxic substances. Interestingly, the transcript level of $L Y Z$ was significantly elevated in the whiteleg shrimp injected with $P E$, suggesting PE treatment could induce certain anti-microbial immune responses.

The proPO cascade is initiated by the binding of pattern-recognition proteins (e.g., lipopolysaccharide- and $\beta$-1,3-glucan binding protein (LGBP), C-type lectin, scavenger receptors, galectins, $\mathrm{PX}$, fibrinogen-related proteins, and $\beta-1,3$-glucan binding protein $(\beta \mathrm{GBP}))$ to non-self microbial substances, such as peptidoglycan, $\beta$-glucan, and lipopolysaccharide, leading to the activation of the melanization process [52]. PX is one of the pattern recognition proteins that bind microbes and transduces signals to hemocytes through integrins [53,54], and is also involved in cell adhesion and encapsulation-promoting activities [55]. PO activity reveals the status of the innate immune response, including associations with phagocytosis, melanization, and cytotoxic reactions [55-57]. In our results, we noticed that PO and phagocytosis activity in PE-treated hemocytes were induced in a dose-dependent manner (Figure 4), suggesting that PE can help to mount immune responses in hemocytes to eliminate invading pathogens, and can also help in wound healing through melanization [58-60]. The gene expression analysis did not show upregulation of $L G B P, P X$, proPO I, or proPO II, implying that PE may only affect the proPO system at the protein level. However, we could not exclude the possibility that these genes may be regulated at earlier or later time points after $\mathrm{PE}$ injection.

$\mathrm{CP}$ and $\mathrm{A} 2 \mathrm{M}$ work as antimicrobial molecules, trapping pathogens by hemocyte clotting [61]. A2M can also inactivate harmful proteases [62]. ALF works as an anticoagulant that inhibits the endotoxin-mediated activation of the coagulation cascade $[63,64]$. Other antimicrobial proteins, such as Cru, ALF, Pen2, Pen3, and Pen4, are known to be important in invertebrates, as they can prevent the spread of pathogens through the blood [65]. Our results show that injection of PE leads to the upregulation of $\mathrm{Cru}, A L F$, and Pen4, but not Pen2, Pen3, $C P$, or $A 2 M$ in hemocytes. However, the mechanisms underlying the modulation of these genes remain to be determined. Taken together, the injection of PE results in the induction of several immune genes, which may be beneficial to hosts challenged by microbial infection.

To test this hypothesis, we conducted two trials that challenged whiteleg shrimp with V. parahaemolyticus or WSSV after injection with SSS buffer or PE. Although injection challenge of whiteleg shrimp is not a natural way of infection, it has been demonstrated to have similar infection performance to naturally infected pathways (e.g., with the nephrocomplex as an entry portal [10]) and reliable reproducibility in indoor systems. In both trials, survival rates were positively related to PE in a dose-dependent manner, supporting the idea that PE could stimulate the immune system of whiteleg shrimp and enhance the survival rate when whiteleg shrimp are faced with either viral and bacterial pathogens.

\section{Conclusions}

This study revealed that a macroalgae (Colaconema sp.) source of PE has immuneregulatory potential, supported by the evidence of the raising of immune parameters and gene expression. Additionally, injections of PE improved the survival rate of whiteleg shrimp after infection by WSSV or $V$. parahaemolyticus. 
Author Contributions: Resources, writing—original draft preparation, and methodology, P.-T.L.; methodology, J.H.; conceptualization and methodology, C.-Y.H.; conceptualization, Z.-X.L.; methodology, H.-Y.Y.; methodology, H.-T.H.; conceptualization and methodology, L.-L.C.; conceptualization and methodology, F.-H.N.; writing-review and editing, methodology, and supervision, M.-C.L. All authors have read and agreed to the published version of the manuscript.

Funding: The authors gratefully acknowledge the financial support from Council of Agriculture, Executive Yuan, Taiwan (Grant number: 1072101011906-150402a4).

Institutional Review Board Statement: Ethical review and approval were waived for this study, due to "Animal Protection Act, Chapter 1, Article 3" from Council of Agriculture, Executive Yuan, Taiwan, "Animal" refers to a dog, a cat and a vertebrate that is raised or kept by people, including the economic animal, the experiment animal, pets and other animals. Therefore, an approval was not necessary for the current research project conducted in Litopenaeus vannamei.

Data Availability Statement: The authors confirm that the data supporting the findings of this study are available within the article.

Acknowledgments: The authors especially thank the editors and anonymous reviewers for their thoughtful comments.

Conflicts of Interest: The authors declare that they have no known competing financial interests or personal relationships that may influence the work reported in this paper.

\section{References}

1. FAO. The State of World Fisheries and Aquaculture 2020; Sustainability in action; FAO: Rome, Italy, 2020.

2. Xu, S.Y.; Huang, X.; Cheong, K.L. Recent Advances in Marine Algae Polysaccharides: Isolation, Structure, and Activities. Mar. Drugs 2017, 15, 388. [CrossRef]

3. Tacon, A. Global trends in aquaculture and compound aquafeed production. World Aquac. 2018, 49, $33-46$.

4. Bachere, E. Anti-infectious immune effectors in marine invertebrates: Potential tools for disease control in larviculture. Aquaculture 2003, 227, 427-438. [CrossRef]

5. Soto-Rodriguez, S.; Gomez-Gil, B. Shrimp Diseases and Molecular Diagnostic Methods. In Aquaculture Microbiology and Biotechnology; Taylor \& Francis Group: Abingdon, UK, 2009; pp. 101-131.

6. Liu, C.-H.; Cheng, W.; Hsu, J.-P.; Chen, J.-C. Vibrio alginolyticus infection in the white shrimp Litopenaeus vannamei confirmed by polymerase chain reaction and $16 \mathrm{~S}$ rDNA sequencing. Dis. Aquat. Org. 2004, 61, 169-174. [CrossRef] [PubMed]

7. Karunasagar, I.; Otta, S.K.; Karunasagar, I. Disease Problems Affecting Cultured Penaeid Shrimp in India. Fish Pathol. 1998, 33, 413-419. [CrossRef]

8. Hasan, M.A.; Siddique, M.; Hasan, M.; Hossain, M.; Rahman, M.S. 16S rRNA gene sequence based identification of Vibrio spp. in shrimp and tilapia hatcheries of Bangladesh. Dhaka Univ. J. Biol. Sci. 2017, 26, 45-58. [CrossRef]

9. Balasubramanian, G.; Sudhakaran, R.; Syed Musthaq, S.; Sarathi, M.; Sahul Hameed, A.S. Studies on the inactivation of white spot syndrome virus of shrimp by physical and chemical treatments, and seaweed extracts tested in marine and freshwater animal models. J. Fish Dis. 2006, 29, 569-572. [CrossRef] [PubMed]

10. De Gryse, G.M.A.; Khuong, T.V.; Descamps, B.; Van Den Broeck, W.; Vanhove, C.; Cornillie, P.; Sorgeloos, P.; Bossier, P.; Nauwynck, H.J. The shrimp nephrocomplex serves as a major portal of pathogen entry and is involved in the molting process. Proc. Natl. Acad. Sci. USA 2020, 117, 28374-28383. [CrossRef]

11. Osunla, C.A.; Okoh, A.I. Vibrio Pathogens: A Public Health Concern in Rural Water Resources in Sub-Saharan Africa. Int. J. Environ. Res. Public Health 2017, 14, 1188. [CrossRef]

12. Immanuel, G.; Sivagnanavelmurugan, M.; Marudhupandi, T.; Radhakrishnan, S.; Palavesam, A. The effect of fucoidan from brown seaweed Sargassum wightii on WSSV resistance and immune activity in shrimp Penaeus monodon (Fab). Fish Shellfish Immunol. 2012, 32, 551-564. [CrossRef] [PubMed]

13. Silva, G.; Costa, R.; Peixoto, J.; Nascimento, F.; Carneiro, P.; Vieira, R. Tropical Atlantic marine macroalgae with bioactivity against virulent and antibiotic resistant Vibrio. Lat. Am. J. Aquat. Res. 2013, 41, 183-188. [CrossRef]

14. Kanjana, K.; Radtanatip, T.; Asuvapongpatana, S.; Withyachumnarnkul, B.; Wongprasert, K. Solvent extracts of the red seaweed Gracilaria fisheri prevent Vibrio harveyi infections in the black tiger shrimp Penaeus monodon. Fish Shellfish Immunol. 2011, 30, 389-396. [CrossRef] [PubMed]

15. Selvin, J.; Manilal, A.; Sugathan, S.; Kiran, S.; Lipton, A. Efficacy of marine green alga Ulva fasciata extract on the management of shrimp bacterial diseases. Lat. Am. J. Aquat. Res. 2011, 39, 197-204. [CrossRef]

16. Sivagnanavelmurugan, M.; Marudhupandi, T.; Palavesam, A.; Immanuel, G. Antiviral Effect of Fucoidan Extracted from the Brown Seaweed, Sargassum wightii, on Shrimp Penaeus monodon Postlarvae against White Spot Syndrome Virus. J. World Aquac. Soc. 2012, 43, 697-706. [CrossRef] 
17. Chen, Y.-Y.; Sim, S.S.; Chiew, S.L.; Yeh, S.-T.; Liou, C.-H.; Chen, J.-C. Dietary administration of a Gracilaria tenuistipitata extract produces protective immunity of white shrimp Litopenaeus vannamei in response to ammonia stress. Aquaculture 2012, 370-371, 26-31. [CrossRef]

18. Apt, K.E.; Collier, J.L.; Grossman, A.R. Evolution of the Phycobiliproteins. J. Mol. Biol. 1995, 248, 79-96. [CrossRef]

19. Sekar, S.; Chandramohan, M. Phycobiliproteins as a commodity: Trends in applied research, patents and commercialization. J. Appl. Phycol. 2008, 20, 113-136. [CrossRef]

20. Six, C.; Thomas, J.C.; Garczarek, L.; Ostrowski, M.; Dufresne, A.; Blot, N.; Scanlan, D.J.; Partensky, F. Diversity and evolution of phycobilisomes in marine Synechococcus spp.: A comparative genomics study. Genome Biol. 2007, 8, R259. [CrossRef]

21. Anwer, K.; Sonani, R.; Madamwar, D.; Singh, P.; Khan, F.; Bisetty, K.; Ahmad, F.; Hassan, M.I. Role of N-terminal residues on folding and stability of C-phycoerythrin: Simulation and urea-induced denaturation studies. J. Biomol. Struct. Dyn. 2015, 33, 121-133. [CrossRef]

22. Soni, B.R.; Hasan, M.I.; Parmar, A.; Ethayathulla, A.S.; Kumar, R.P.; Singh, N.K.; Sinha, M.; Kaur, P.; Yadav, S.; Sharma, S.; et al. Structure of the novel $14 \mathrm{kDa}$ fragment of $\alpha$-subunit of phycoerythrin from the starving cyanobacterium Phormidium tenue. J. Struct. Biol. 2010, 171, 247-255. [CrossRef]

23. Sonani, R.R.; Singh, N.K.; Kumar, J.; Thakar, D.; Madamwar, D. Concurrent purification and antioxidant activity of phycobiliproteins from Lyngbya sp. A09DM: An antioxidant and anti-aging potential of phycoerythrin in Caenorhabditis elegans. Process. Biochem. 2014, 49, 1757-1766. [CrossRef]

24. Sonani, R.R.; Singh, N.K.; Awasthi, A.; Prasad, B.; Kumar, J.; Madamwar, D. Phycoerythrin extends life span and health span of Caenorhabditis elegans. Age 2014, 36, 9717. [CrossRef]

25. Sonani, R.R.; Rastogi, R.P.; Singh, N.K.; Thadani, J.; Patel, P.J.; Kumar, J.; Tiwari, A.K.; Devkar, R.V.; Madamwar, D. Phycoerythrin averts intracellular ROS generation and physiological functional decline in eukaryotes under oxidative stress. Protoplasma 2017, 254, 849-862. [CrossRef]

26. Hemlata Afreen, S.; Fatma, T. Extraction, purification and characterization of phycoerythrin from Michrochaete and its biological activities. Biocatal. Agric. Biotechnol. 2018, 13, 84-89. [CrossRef]

27. Hernández-López, J.; Gollas-Galván, T.; Vargas-Albores, F. Activation of the prophenoloxidase system of the brown shrimp Penaeus californiensis Holmes). Comp. Biochem. Physiol. Part C Pharmacol. Toxicol. Endocrinol. 1996, 113, 61-66. [CrossRef]

28. Xian, J.-A.; Wang, A.-L.; Tian, J.-X.; Huang, J.-W.; Ye, C.-X.; Wang, W.-N.; Sun, R.-Y. Morphologic, physiological and immunological changes of haemocytes from Litopenaeus vannamei treated by lipopolysaccharide. Aquaculture 2009, 298, 139-145. [CrossRef]

29. Elshopakey, G.E.; Risha, E.F.; Abdalla, O.A.; Okamura, Y.; Hanh, V.D.; Ibuki, M.; Sudhakaran, R.; Itami, T. Enhancement of immune response and resistance against Vibrio parahaemolyticus in kuruma shrimp (Marsupenaeus japonicus) by dietary

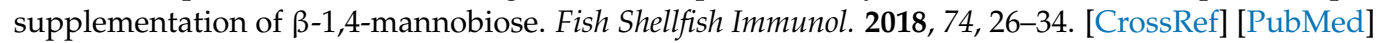

30. Lee, Y.-K.; Chew, P.-F.; Soh, B.-S.; Tham, L.Y. Enhancing phagocytic activity of hemocytes and disease resistance in the prawn Penaeus merguiensis by feeding Spirulina platensis. J. Appl. Phycol. 2003, 15, 279-287. [CrossRef]

31. Xian, J.-A.; Wang, A.-L.; Ye, C.-X.; Chen, X.-D.; Wang, W.-N. Phagocytic activity, respiratory burst, cytoplasmic free-Ca ${ }^{2+}$ concentration and apoptotic cell ratio of haemocytes from the black tiger shrimp, Penaeus monodon under acute copper stress. Comp. Biochem. Physiol. Part C Toxicol. Pharmacol. 2010, 152, 182-188. [CrossRef] [PubMed]

32. Jiang, S.; Jia, Z.; Zhang, T.; Wang, L.; Qiu, L.; Sun, J.; Song, L. Functional characterisation of phagocytes in the Pacific oyster Crassostrea gigas. Peer] 2016, 4, e2590. [CrossRef]

33. Chen, Y.-Y.; Chen, J.-C.; Lin, Y.-C.; Yeh, S.-T.; Huang, C.-L. White Shrimp Litopenaeus vannamei That Have Received Gracilaria tenuistipitata Extract Show Early Recovery of Immune Parameters after Ammonia Stressing. Mar. Drugs 2015, 13, 3606-3624. [CrossRef]

34. Cheng, W.; Liu, C.-H.; Tsai, C.-H.; Chen, J.-C. Molecular cloning and characterisation of a pattern recognition molecule, lipopolysaccharide- and $\beta-1,3$-glucan binding protein (LGBP) from the white shrimp Litopenaeus vannamei. Fish Shellfish Immunol. 2005, 18, 297-310. [CrossRef]

35. Liu, C.-H.; Cheng, W.; Kuo, C.-M.; Chen, J.-C. Molecular cloning and characterisation of a cell adhesion molecule, peroxinectin from the white shrimp Litopenaeus vannamei. Fish Shellfish Immunol. 2004, 17, 13-26. [CrossRef]

36. Chen, Y.-Y.; Chen, J.-C.; Lin, Y.-C.; Putra, D.F.; Kitikiew, S.; Li, C.-C.; Hsieh, J.-F.; Liou, C.-H.; Yeh, S.-T. Shrimp that have received carrageenan via immersion and diet exhibit immunocompetence in phagocytosis despite a post-plateau in immune parameters. Fish Shellfish. Immunol. 2014, 36, 352-366. [CrossRef]

37. Han-Ching Wang, K.C.; Tseng, C.-W.; Lin, H.-Y.; Chen, I.T.; Chen, Y.-H.; Chen, Y.-M.; Chen, T.-Y.; Yang, H.-L. RNAi knock-down of the Litopenaeus vannamei Toll gene (LvToll) significantly increases mortality and reduces bacterial clearance after challenge with Vibrio harveyi. Dev. Comp. Immunol. 2010, 34, 49-58. [CrossRef]

38. Ezra-Elia, R.; Obolensky, A.; Ejzenberg, A.; Ross, M.; Mintz, D.; Banin, E.; Ofri, R. Can an in vivo imaging system be used to determine localization and biodistribution of AAV5-mediated gene expression following subretinal and intravitreal delivery in mice? Exp. Eye Res. 2018, 176, 227-234. [CrossRef]

39. Wang, T.; Diaz-Rosales, P.; Costa, M.M.; Campbell, S.; Snow, M.; Collet, B.; Martin, S.A.M.; Secombes, C.J. Functional characterization of a nonmammalian IL-21: Rainbow trout Oncorhynchus mykiss IL-21 upregulates the expression of the Th cell signature cytokines IFN-gamma, IL-10, and IL-22. J. Immunol. 2011, 186, 708. [CrossRef] [PubMed] 
40. Hong, X.; Lu, L.; Xu, D. Progress in research on acute hepatopancreatic necrosis disease (AHPND). Aquac. Int. 2016, 24, 577-593. [CrossRef]

41. Sánchez-Muros, M.J.; Renteria, P.; Vizcaino, A.; Barroso, F.G. Innovative protein sources in shrimp (Litopenaeus vannamei) feeding. Rev. Aquac. 2020, 12, 186-203. [CrossRef]

42. Huynh, T.-G.; Yeh, S.-T.; Lin, Y.-C.; Shyu, J.-F.; Chen, L.-L.; Chen, J.-C. White shrimp Litopenaeus vannamei immersed in seawater containing Sargassum hemiphyllum var. chinense powder and its extract showed increased immunity and resistance against Vibrio alginolyticus and white spot syndrome virus. Fish Shellfish Immunol. 2011, 31, 286-293. [CrossRef] [PubMed]

43. Wang, C.; Shen, Z.; Li, L.; Li, Y.; Zhao, H.; Jiang, X. Immunomodulatory activity of R-phycoerythrin from Porphyra haitanensis via TLR4/NF-kB-dependent immunocyte differentiation. Food Funct. 2020, 11, 2173-2185. [CrossRef]

44. Bermejo, R.; Acién, F.G.; Ibáñez, M.J.; Fernández, J.M.; Molina, E.; Alvarez-Pez, J.M. Preparative purification of B-phycoerythrin from the microalga Porphyridium cruentum by expanded-bed adsorption chromatography. J. Chromatogr. B Anal. Technol. Biomed. Life Sci. 2003, 790, 317-325. [CrossRef]

45. Sakai, S.; Komura, Y.; Nishimura, Y.; Sugawara, T.; Hirata, T. Inhibition of Mast Cell Degranulation by Phycoerythrin and Its Pigment Moiety Phycoerythrobilin, Prepared from Porphyra yezoensis. Food Sci. Technol. Res. 2011, 17, 171-177. [CrossRef]

46. Senthilkumar, N.; Suresh, V.; Thangam, R.; Kurinjimalar, C.; Kavitha, G.; Murugan, P.; Kannan, S.; Rengasamy, R. Isolation and characterization of macromolecular protein R-Phycoerythrin from Portieria hornemannii. Int. J. Biol. Macromol. 2013, 55, 150-160. [CrossRef] [PubMed]

47. Smith, V.J.; Brown, J.H.; Hauton, C. Immunostimulation in crustaceans: Does it really protect against infection? Fish Shellfish Immunol. 2003, 15, 71-90. [CrossRef]

48. Song, Y.-L.; Hsieh, Y.-T. Immunostimulation of tiger shrimp (Penaeus monodon) hemocytes for generation of microbicidal substances: Analysis of reactive oxygen species. Dev. Comp. Immunol. 1994, 18, 201-209. [CrossRef]

49. Yang, H.-T.; Yang, M.-C.; Sun, J.-J.; Guo, F.; Lan, J.-F.; Wang, X.-W.; Zhao, X.-F.; Wang, J.-X. Catalase eliminates reactive oxygen species and influences the intestinal microbiota of shrimp. Fish Shellfish Immunol. 2015, 47, 63-73. [CrossRef]

50. Nordberg, J.; Arner, E.S. Reactive oxygen species, antioxidants, and the mammalian thioredoxin system. Free. Radic. Biol. Med. 2001, 31, 1287-1312. [CrossRef]

51. Holmblad, T.; Söderhäll, K. Cell adhesion molecules and antioxidative enzymes in a crustacean, possible role in immunity. Aquaculture 1999, 172, 111-123. [CrossRef]

52. Amparyup, P.; Charoensapsri, W.; Tassanakajon, A. Prophenoloxidase system and its role in shrimp immune responses against major pathogens. Fish Shellfish Immunol. 2013, 34, 990-1001. [CrossRef]

53. Wang, X.-W.; Wang, J.-X. Pattern recognition receptors acting in innate immune system of shrimp against pathogen infections. Fish Shellfish Immunol. 2012, 34, 981-989. [CrossRef] [PubMed]

54. Jiravanichpaisal, P.; Lee, B.L.; Söderhäll, K. Cell-mediated immunity in arthropods: Hematopoiesis, coagulation, melanization and opsonization. Immunobiology 2006, 211, 213-236. [CrossRef] [PubMed]

55. Cerenius, L.; Lee, B.L.; Söderhäll, K. The proPO-system: Pros and cons for its role in invertebrate immunity. Trends Immunol. 2008, 29, 263-271. [CrossRef]

56. Cerenius, L.; Söderhäll, K. The prophenoloxidase-activating system in invertebrates. Immunol. Rev. 2004, 198, 116-126. [CrossRef]

57. Nappi, A.J.; Christensen, B.M. Melanogenesis and associated cytotoxic reactions: Applications to insect innate immunity. Insect Biochem. Mol. Biol. 2005, 35, 443-459. [CrossRef]

58. Cerenius, L.; Babu, R.; Söderhäll, K.; Jiravanichpaisal, P. In vitro effects on bacterial growth of phenoloxidase reaction products. J. Invertebr. Pathol. 2010, 103, 21-23. [CrossRef]

59. Cerenius, L.; Söderhäll, K. 2-Crustacean immune responses and their implications for disease control. In Infectious Disease in Aquaculture; Austin, B., Ed.; Woodhead Publishing: Sawston, UK, 2012; pp. 69-87.

60. Novoa, B.; Figueras, A. 3-Immune responses in molluscs and their implications for disease control. In Infectious Disease in Aquaculture; Austin, B., Ed.; Woodhead Publishing: Sawston, UK, 2012; pp. 88-110.

61. Maningas, M.B.; Kondo, H.; Hirono, I. Molecular mechanisms of the shrimp clotting system. Fish Shellfish Immunol. 2012, 34, 968-972. [CrossRef]

62. Chaikeeratisak, V.; Somboonwiwat, K.; Tassanakajon, A. Shrimp Alpha-2-Macroglobulin Prevents the Bacterial Escape by Inhibiting Fibrinolysis of Blood Clots. PLoS ONE 2012, 7, e47384. [CrossRef]

63. Tanaka, S.; Nakamura, T.; Morita, T.; Iwanaga, S. Limulus anti-LPS factor: An anticoagulant which inhibits the endotoxin mediated activation of Limulus coagulation system. Biochem. Biophys. Res. Commun. 1982, 105, 717-723. [CrossRef]

64. Zhan, W.; He, L.; Wei, X.; Wang, X.; Tang, X. An Anti-Lipopolysaccharide Factor in Litopenaeus Vannamei Participates in the Immune Defense Against WSSV and Vibrio Anguillarum. J. Crustacean Biol. 2015, 35, 670-675. [CrossRef]

65. Loker, E.S.; Adema, C.M.; Zhang, S.M.; Kepler, T.B. Invertebrate immune systems-not homogeneous, not simple, not well understood. Immunol. Rev. 2004, 198, 10-24. [CrossRef] [PubMed] 